\title{
Diversity of Lactifluus (Basidiomycota, Russulales) in West Africa: 5 new species described and some considerations regarding their distribution and ecology
}

\author{
Maba DL $1,2^{*}$, Guelly AK ${ }^{1}$, Yorou NS ${ }^{3}$ and Agerer $\mathbf{R}^{2}$ \\ ${ }^{1}$ Département de Botanique et Écologie Végétale, Faculté des Sciences, Université de Lomé $\square$ BP 1515, Lomé, Togo. $\square$ \\ ${ }^{2}$ Department Biology I, Organismic Biology: Mycology, Ludwig-Maximilians-Universität München, Menzinger Str. 67, \\ 80638 München, Germany. \\ ${ }^{3}$ Faculty of Agronomy, University of Parakou, BP 123, Parakou, Benin. $\square$
}

Maba DL, Guelly AK, Yorou NS, Agerer R 2015 - Diversity of Lactifluus (Basidiomycota, Russulales) in West Africa: 5 new species described and some considerations regarding their distribution and ecology. Mycosphere 6(6), 737-759, Doi 10.5943/mycosphere/6/6/9

\begin{abstract}
The genus Lactifluus is one of the common ectomycorrhizal fungal taxa in tropical African forest ecosystems. Recent morphological and anatomical mycological studies based on specimens we sampled from 2007 to 2013 in West African forest ecosystems, including dry, dense, riparian forests and woodlands, enable to assess the diversity and the occurrence of Lactifluus species in the Guineo-Sudanian domain. A total of 51 ITS rDNA sequences generated from our samples were aligned against tropical African and worldwide Lactifluus sequences available in GenBank. A Maximum Likelihood phylogenetic tree was inferred from 113 sequences. The phylogenetic placement of the species, combined with our morpho-anatomical data, supported the description of five new species distributed among Lactifluus species. Our data further confirm that the species richness of the genus Lactifluus is high and partly unexplored in the Guineo-Sudanian domain, and confirmed that, in both the Guineo-Sudanian and the Congo-Zambezian domain many common species occur. Patterns of occurrence of the recorded Lactifluus species from Guineo-Sudanian ecozones are also highlighted.
\end{abstract}

Key words - Guineo-Sudanian - milkcaps - morpho-anatomy - molecular phylogeny - taxonomy

\section{Introduction}

Although there has been remarkable progress in tropical mycological investigations for the last twenty years, tropical African ecozones, and particularly West Africa, remain very poorly explored (van Roiij et al. 2003, Rivière et al. 2007, Diédhiou et al. 2013). In Guineo-Sudanian forest ecosystems, the genera Scleroderma, Tomentella, Russula, Lactarius (L.) and Lactifluus (Lf.) are among the most studied ectomycorrhizal fungi (ECM) (van Rooij et al. 2003, Yorou et al. 2011, 2012, Verbeken \& Walleyn 2010, Sanon et al. 2013, Maba et al. 2013, 2014, 2015, Sanon et al. 2014). Recent progress in molecular phylogenetic analyses and morpho-anatomical investigations within lactarioid taxa (Buyck et al. 2008, Verbeken \& Walleyn 2010, Van de Putte et al. 2010, Stubbe et al. 2010, Verbeken et al. 2011, De Crop et al. 2014, Maba et al. 2013, 2014, 2015) 
highlighted the high genetic diversity of the genus Lactifluus, with numerous new species and cryptic species described from tropical Africa (Verbeken et al. 2008, Van de Putte et al. 2009, De Crop et al. 2012, Maba et al. 2013, 2015). In order to better circumscribe species limits and the ecological plasticity of Lactifluus species, mycological investigations have been undertaken from specimens collected in West African forest ecosystems (Maba et al. 2013, 2014, 2015).

Maba et al. (2015) undertook molecular analysis of Lactifluus taxa, including unidentified specimens from West Africa. In addition to considerations regarding ecology, the present study provides morpho-anatomical support for new Lactifluus species identification. Thus, from numerous specimens we sampled, five Lactifluus specimens of which the molecular phylogenetic positions are supported by Maba et al. (2015), are described hereby as new species to science, based on morpho-anatomical differences with most closely related species. The newly described Lactifluus species are accommodated in subgenera Lactariopsis (two species), Russulopsis (one species) and Edules (two species). Chorological patters of recorded Lactifluus species in West Africa and their putative host trees are discussed.

\section{Material and Methods}

Specimens were sampled between 2007 and 2013 in various West African forest ecosystems, including the northern Guinean seasonal, dry, dense, riparian and open forests, woodlands and savannas following a megatransect through five countries (Benin, Togo, Burkina Faso, Mali, and Guinea). The specimens described here were sampled from DAN riverside forest in south-western part of Burkina Faso (MD355); in Malouwaita rainforest of Guinea (MD219B, MD224 and MD234). Specimens (C2349, MD123 and MD131) were sampled in Fazao-Malfakassa National Park, whereas specimens DPM05, C2157 and C2163 were sampled in Aledjo Reserve forest, all in central Togo. Sampling techniques, records of preliminary morphological data as well as specimens' preparation for conservation are detailed previously (Maba et al. 2013). Colours were recorded following Kornerup \& Wanscher (1978). Holotypes of the new species are conserved in TOGO herbarium and isotypes in GENT and M (Thiers 2012).

\section{Light and Scanning Electron Microscopy}

Microscopical studies were performed focusing on the lactarioids anatomical diagnostic features, following Verbeken \& Walleyn (2010) and Maba et al. (2013, 2014, 2015). Measurements are given referring to Buyck (1991) and detailed by Maba et al. (2013). Comparative microscopic studies also integrated specimens of Lactifluus zenkeri (A MA. 20) and L. sesemotani (AV94-471 and AV94-82) received from Ghent University as loans. SEM micrographs were obtained using the procedures explained by Maba et al. (2013). Preliminary identification of specimens were made using the Lactarius s. 1. study based on material collected in similar ecosystems in the neighboring country Benin (van Rooij et al. 2003) and the monograph of Verbeken \& Walleyn (2010) about tropical African Lactarius s. 1.

\section{DNA Extraction, sequencing and PCR amplification}

Genomic DNA extraction, sequencing and PCR amplification were undertaken by Maba et al. (2015). The internal transcribed spacer regions (ITS) of the nuclear ribosomal DNA including ITS1, ITS2 and 5.8S regions were amplified using the fungal specific primer ITS1F in combination with the basidiomycete specific primer ITS4B (Gardes \& Bruns 1993). A total of 51 ITS sequences were obtained and the sequences of the newly described species have been deposited at European Nucleotide Archive/ENA (Table 1).

\section{Sequence editing, analyses and molecular phylogenetic inference}

We refer to Maba et al. (2015) for sequence editing, analyses and phylogenetic inference (Supplement). Four new sequences (three newly generated and one obtained from GenBank) were added to the sequence dataset compiled in Maba et al. (2015). The multiple sequence alignment and procedure for phylogenetic tree inference refer to Maba et al. (2015) and the Maximum Likelihood 
Table 1 - List of our generated and public Genbank sequences included in phylogenetic analyses

\begin{tabular}{|c|c|c|}
\hline Species & ENA, accession numbers & Localities \\
\hline \multicolumn{3}{|l|}{ Lactifluus (81 sequences) } \\
\hline Lactifluus allardii & KF220017, KF220015 & USA \\
\hline Lactifluus annulatoangustifolius & HG426475 & Togo \\
\hline Lactifluus annulatoangustifolius & AY606981 & Madagascar \\
\hline Lactifluus annulatolongisporus sp. nov.* & HG426470, LK392606 & Togo \\
\hline Lactifluus atrovelutinus & GU258231 & Malaysia \\
\hline Lactifluus burkinabei sp. nov.* & LK392609 & Burkina Faso \\
\hline Lactifluus brunneocarpus sp. nov.* & LK392608 & Guinea \\
\hline Lactifluus chamaeleontinus & AY606980 & Zambia \\
\hline Lactifluus chiapanensis & GU258297 & Mexico \\
\hline Lactifluus clarkeae & HQ318283 & Australia \\
\hline Lactifluus clarkeae & GU222280 & New Zealand \\
\hline Lactifluus crocatus & HQ318265, Q318248, HQ318266 & Thailand \\
\hline Lactifluus denigricans & AY606983 & Benin \\
\hline Lactifluus densifolius & HG917385 & Togo \\
\hline Lactifluus edulis & HG917384 & Togo \\
\hline Lactifluus emergens & HG426467 & Togo \\
\hline Lactifluus emergens & AY606979 & Zimbabwe \\
\hline Lactifluus fazaoensis & HG426477 & Togo \\
\hline Lactifluus flammans & HG426471 & Togo \\
\hline Lactifluus flammans & UDB016931 & Benin \\
\hline Lactifluus flavellus & LK392594, LK392595 & Togo \\
\hline Lactifluus flocktonae & JX2666621, JX266622 & Australia \\
\hline Lactifluus foetens & HG917381 & Togo \\
\hline Lactifluus foetens & LK392603 & Burkina Faso \\
\hline Lactifluus genevievae & GU258294 & Australia \\
\hline Lactifluus glaucescens & KF220117 & Italy \\
\hline Lactifluus glaucescens & KF220094 & Belgium \\
\hline Lactifluus glaucescens & KF220075 & France \\
\hline Lactifluus guellii sp. nov.* & HG426466 & Togo \\
\hline Lactifluus gymnocarpoides & LK392601 & Benin \\
\hline Lactifluus gymnocarpoides & LK392600 & Benin \\
\hline Lactifluus gymnocarpus & HG426472 & Togo \\
\hline Lactifluus heimii & LK392612 & Togo \\
\hline Lactifluus hygrophoroides & JN129397 & China \\
\hline Lactifluus inversus & AY606976 & Guinea \\
\hline Lactifluus longibasidius & LK392596, HG426473 & Togo \\
\hline Lactifluus longipes & HG917391, HG917383 & Togo \\
\hline Lactifluus longipilus & HQ318235, HQ318258, KF432958 & Thailand \\
\hline Lactifluus longisporus & DQ421971 & Zambia \\
\hline Lactifluus luteopus & LK392602 & Togo \\
\hline Lactifluus luteopus & LK392611 & Burundi \\
\hline Lactifluus medusae & HG426474 & Togo \\
\hline Lactifluus madagascariensis & AY606977 & Madagascar \\
\hline Lactifluus melleus & LK392598, LK392597 & Togo \\
\hline Lactifluus membranaceus sp. nov.* & LK392610 & Guinea \\
\hline Lactifluus membranaceus sp. nov.* & HG426478 & Togo \\
\hline Lactifluus nodosicystidiosus & AY606975 & Madagascar \\
\hline Lactifluus nonpiscis & HG426468 & Togo \\
\hline Lactifluus pectinatus & LK392599 & Togo \\
\hline Lactifluus piperatus & KF220122, KF220120 & France \\
\hline Lactifluus pelliculatus & AY606978 & Madagascar \\
\hline Lactifluus phlebophyllus & AY606074 & Madagascar \\
\hline Lactifluus pseudoluteopus & HQ318286 & Thailand \\
\hline Lactifluus rubroviolascens & AY606984 & Zambia \\
\hline Lactifluus rubroviolascens & AY606985 & Madagascar \\
\hline Lactifluus rubiginosus & HG917386 & Togo \\
\hline Lactifluus sudanicus & HG426469, HG426476 & Togo \\
\hline Lactifluus velutissimus & AY606982 & Zimbabwe \\
\hline
\end{tabular}




\begin{tabular}{|c|c|c|}
\hline Species & ENA, accession numbers & Localities \\
\hline Lactifluus volemus & HQ318279, HQ318275 & Thailand \\
\hline Lactifluus volemoides & UDB016930 & Benin \\
\hline Lactifluus sp. & LK392607 & Togo \\
\hline Lactifluus sp. & LK931501 & Togo \\
\hline Lactifluus sp. & LK392604 & Benin \\
\hline Lactifluus sp. & LK392605 & Benin \\
\hline Lactifluus sp. & LM999911 & Benin \\
\hline Lactifluus sp. & LN651269 & Burkina Faso \\
\hline Lactifluus sp. & LM999910 & Togo \\
\hline Lactifluus sp. & UDB014027 & Cameroon \\
\hline \multicolumn{3}{|l|}{ Lactarius (17 sequences) } \\
\hline Lactarius baliophaeus & GU258277 & Zambia \\
\hline Lactarius kabansus & HG917376 & Togo \\
\hline Lactarius kabansus & HG917390 & Zimbabwe \\
\hline Lactarius miniatescens & HG917375 & Burkina Faso \\
\hline Lactarius miniatescens & HG917374 & Togo \\
\hline Lactarius tenellus & HG917373 & Togo \\
\hline Lactarius saponaceus & HG917379 & Guinea \\
\hline Lactarius saponaceus & HG917378 & Togo \\
\hline Lactarius subbaliophaeus & HG917372 & Togo \\
\hline Lactarius sp. & UDB013804 & Zambia \\
\hline Lactarius sp. & UDB015091 & Gabon \\
\hline Lactarius sp. & UDB018664 & Zambia \\
\hline Lactarius sp. & UDB018662 & Zambia \\
\hline Lactarius sp. & UDB013845 & Zambia \\
\hline Lactarius sp. & UDB013930 & Cameroon \\
\hline Lactarius sp. & UDB016860 & Zambia \\
\hline Lactarius sp. & UDB013836 & Zambia \\
\hline \multicolumn{3}{|l|}{ Multifurca (5 sequences) } \\
\hline Multifurca zonaria & DQ422000, DQ421990 & Thailand \\
\hline Multifurca furcata & DQ421995, DQ421994 & USA \\
\hline Multifurca ochricompacta & DQ421984 & USA \\
\hline \multicolumn{3}{|l|}{ Russula (8 sequences) } \\
\hline Russula cremeirosea & EU819424 & USA \\
\hline Russula congoana & HG917387 & Togo \\
\hline Russula congoana & UDB016932 & Benin \\
\hline Russula compressa & UDB016985 & Benin \\
\hline Russula discopus & JQ902046 & Burundi \\
\hline Russula discopus & JQ902050 & Senegal \\
\hline Russula lipida & JF908663 & Italy \\
\hline Russula xerampilina & KF386758 & USA \\
\hline \multicolumn{3}{|l|}{ Out group ( 2 sequences) } \\
\hline Gloeocystidiellum sp.? & KJ140715 & USA \\
\hline Hericium erinaceum & EU784265 & Kew \\
\hline
\end{tabular}

(*) Newly described species

(ML) tree obtained has included a total of 113 ITS sequences (Tab. 1, Supplement). The alignment is submitted to TreeBASE (http://purl.org/phylo/treebase/phylows/study/TB2:S17549).

\section{Results}

\section{ITS sequence analyses}

Sequences of the target specimens (MD123, MD131, MD224, MD234, MD355, C2157, and C2349) are supported in the clade that encompasses representatives of Lactifluus subgenera Lactariopsis, Edules and Russulopsis (Fig. 1). The sequences of two newly described species (MD123 and MD131, C2349 and MD234) cluster within the Lf. subg. Lactariopsis subclade, with $98 \%$ and $57 \%$ of bootstrap support respectively, with already known species (subclade I). The subclade II encompasses sequences of unidentified specimens from Togo (MD154) and Benin 


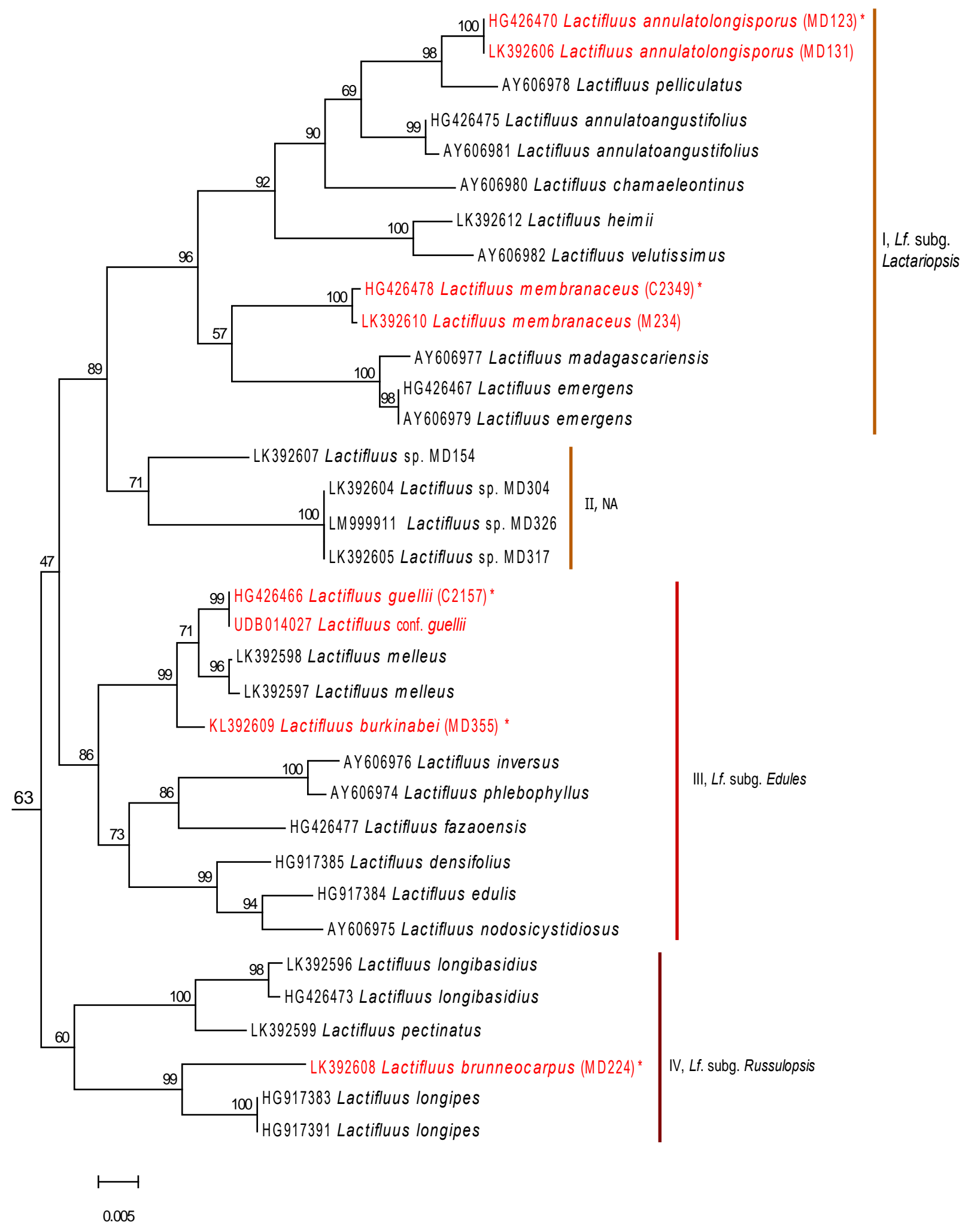

Fig. 1 - Phylogenetic tree obtained from ITS sequences. Bootstrap values (in \%) are from maximum likelihood (ML) analyses (1000 bootstraps). Lactifluus (subgenera Lactariopsis, Edules and Russulopsis) subtree showing the five newly described species: Lf. annulatolongisporus, Lf. brunneocarpus, Lf. burkinabei, Lf. guellii and Lf. membranaceus. (*) is mentioned in front for the holotypes. 
(MD304, MD317, and MD326). At the same time the sequences of the specimens C2157 and MD355 (two newly described species), fit in $L f$. subg. Edules, with respectively $71 \%$ and $99 \%$ of bootstrap support with already known species (subclade III). In Lf. subg. Russulopsis subclade (IV), nested the sequence of one new described species (MD224), supported by $99 \%$ of bootstrap value as sister species of $L f$. longipes.

The morpho-anatomical analyses reveal deviating features between specimen MD123, MD131, MD219B, MD224, MD234, MD355, C2157, C2163, C2349 and DPM05, and their morphological closely related species. These deviating features, coupled with the phylogenetic placement of the specimens, accommodates them into five new species, notably: Lactifluus annulatolongisporus (specimens MD123 and MD131) and Lactifluus membranaceus (C2349, DPM05 and MD234) within Lf. subg. Lactariopsis; Lactifluus brunneocarpus (MD219B and MD224) in Lf. subg. Russulopsis, and Lactifluus burkinabei (MD355) and Lactifluus guellii (C2157 and C2163), both within $L f$. subg. Edules.

\section{Taxonomy}

Lactifluus annulatolongisporus Maba, sp. nov.

Figs $2-4$

Mycobank MB811601,

Facesoffungi Number: FoF 01642

Genbank ENA, accession number HG426470

Etymology - Referring to the presence of an annulus and the basidiospores that are strongly elongate.

Pileus (Fig. 2A-C) 40-65 mm diam., plano-convex, depressed to umbilicate, slightly subinfundibuliform; remnants of secondary/partial velum forming an evanescent annulus; margin first incurved then crenulate; pellis pruinose, dry, not dehiscent; whitish, orange white at the margin, pale orange in the center, appearing zonate-like. Lamellae slightly crowded, broadly adanate to subdecurrent, irregular, unequal; 1 or 3 lamellulae between 2 lamellae $(\mathrm{L}+\mathrm{l}=7-10 / \mathrm{cm})$. Stipe 30-40 × 10-15 mm; cylindrical, tapering downwards; fleshy and firm. Context whitish to fleshy, firm; thick in the center of the pileus and thin near margin. Latex not abundant, whitish and unchanging.

Basidiospores (Fig. 3C, 4A-C) strongly elongate, rarely ellipsoid (9)10-10.5-11(11.5) $\times$ (5.5)6.0-7.0-7.5(8) $\mu \mathrm{m}(\mathrm{Q}=1.3-1.4-1.5-1.6-1.7 ; \mathrm{n}=120)$; ornamentation amyloid, composed of very short warts, fine lines, thicker in their middle part, not clearly distinguishable under light microscope; very low warts slightly connected (as seen in scanning electron microscope); amyloid spot in the plage distinctly present (Fig. 3C). Basidia (Fig. 3B) 40-65 $\times 10-12 \mu \mathrm{m}$, subcylindrical and four-spored. Pleurocystidia absent. Pleuropseudocystidia (Fig. 3D) 6-30 $\mu \mathrm{m}$ diam., very abundant, clavate to conical, rarely subcylindrical, sometimes bifurcate, apex micronate or capitate, sometimes emergent up to $50 \mu \mathrm{m}$ above the hymenium, contents needle-like. Lamellar edge sterile. Hymenophoral trama composed of a mixture of filamentous hyphae, sphaerocytes and lactifers. Marginal cells (Fig. 3E) 25-60 × 4-11 $\mu \mathrm{m}$, utriform, tortuous, dichotomously branched. Pileipellis (Fig. 3B) a lamprotrichopalisade, terminal elements thick-walled very slender, up to $240 \mu \mathrm{m}$ long, septate, sometimes forked or branched. Stipitipellis identical to pileipellis. Clamps absent.

Material examined - Togo, Central region, Prefecture of Tchaoudjo, Fazao-Malfakassa National Park, N08 42'58" E00 46'22", on soil, in woodland dominated by Isoberlinia doka and Uapaca togoensis, 18 June 2011, (collector) D.L. Maba, MD123 (TOGO, holotype), AV11-147 (GENT, Isotype); Togo, Central region, Prefecture of Tchaoudjo, Fazao-Malfakassa National Park, N08 $42^{\prime}$ 24" E00 45' 08", on soil in woodland dominated by Isoberlinia doka, and Uapaca togoensis, 18 June 2011, (collector) D.L. Maba, MD131 (TOGO, holotype), ENA acc. no. LK392606.

Known distribution - Togo, Fazao-Malfakassa National Park. 

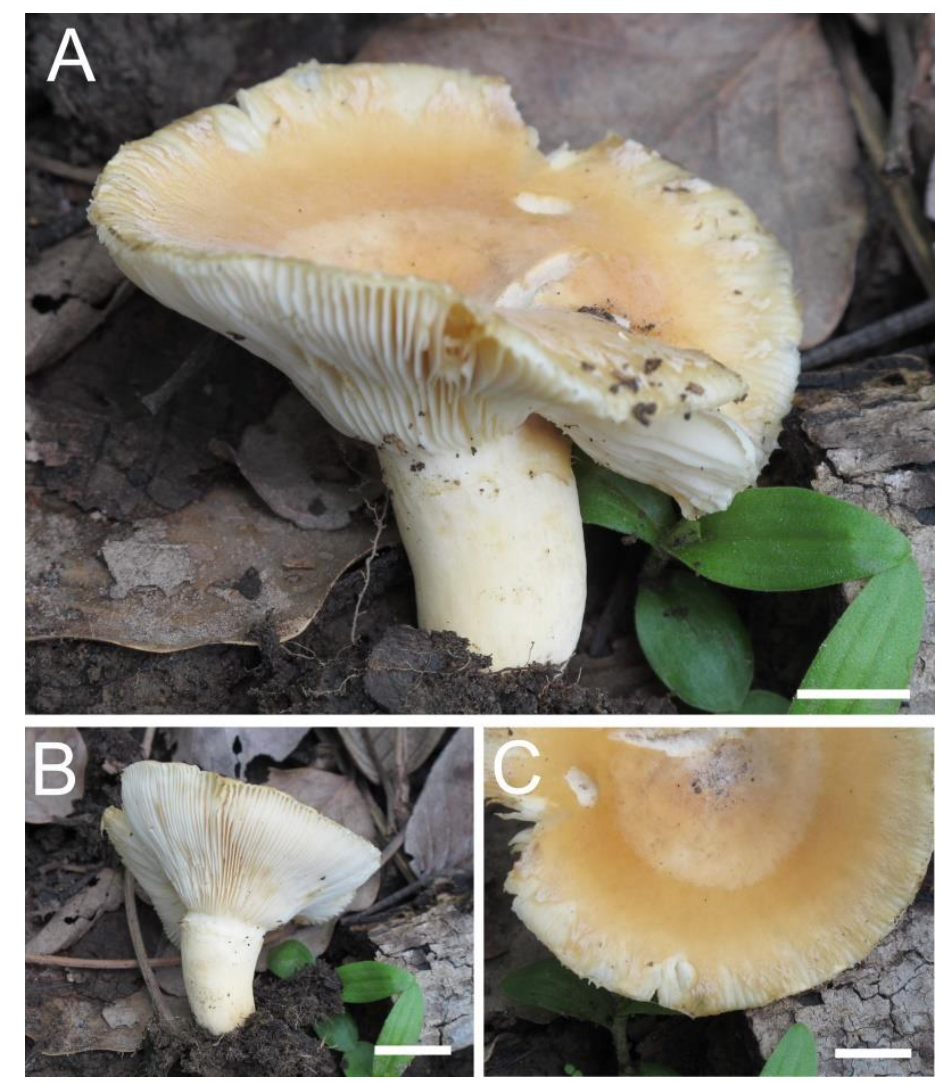

Fig. 2 - Basidiome of Lactifluus annulatolongisporus (MD123). A. Detailed view. B. Lamellae and stipe detailed. C. Pileus view, pellis detailed. - Scale Bars $=10 \mathrm{~mm}$.
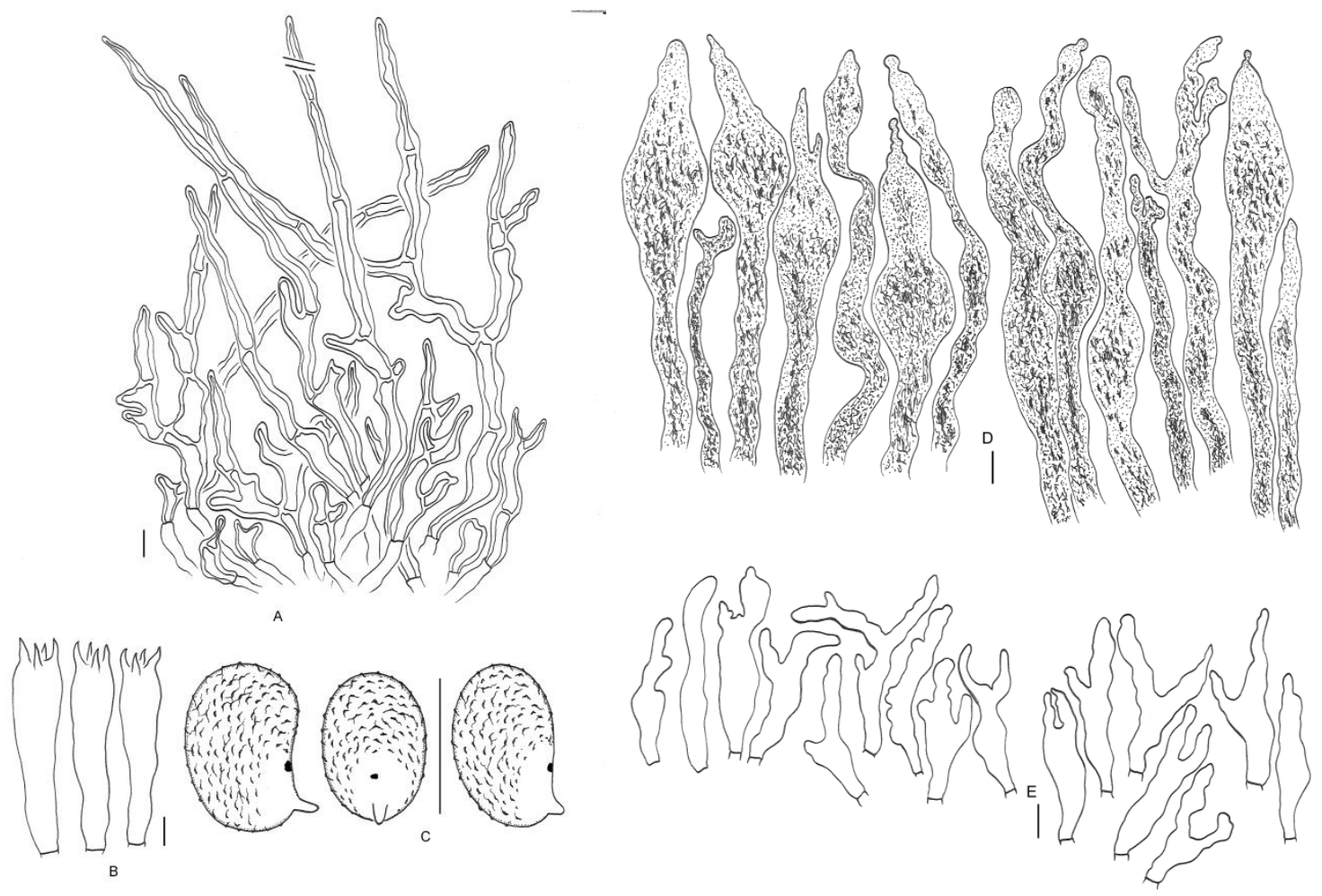

Fig. 3 - Light microscopy of Lactifluus annulatolongisporus. A. Pileipellis B. Basidia. C. Basidiospores D. Pleuropseudocystidia, MD123 (left); MD131 (right). E. Marginal cells, MD131 (left); MD123 (right). - Scale Bars $=10 \mu \mathrm{m}$. Section line drawing 

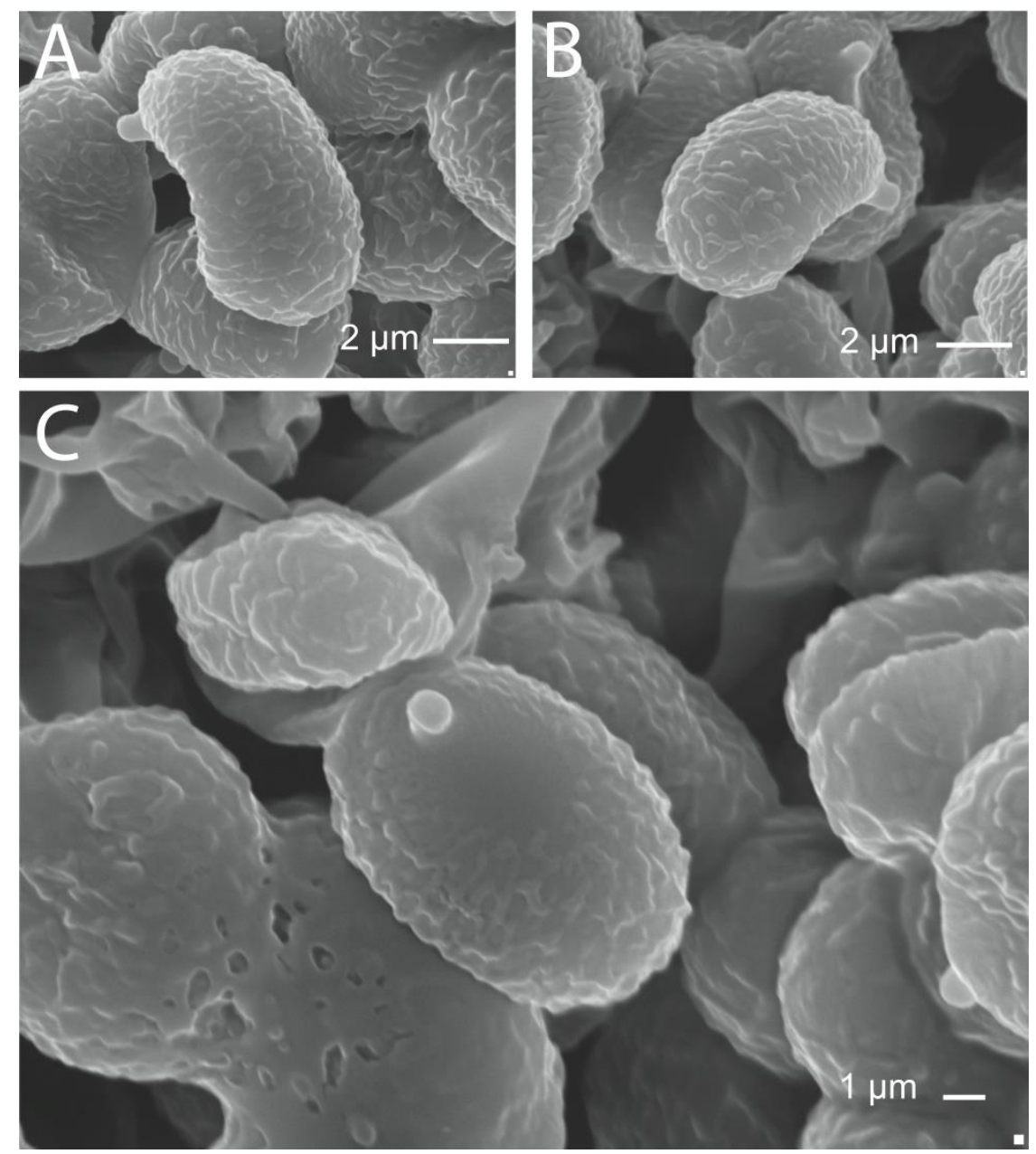

Fig. 4 - SEM of Lactifluus annulatolongisporus (MD123). Basidiospores: A-B. Dorsal view. C. Lateral and detailed view showing the plage.

Lactifluus brunneocarpus Maba, sp. nov.

Figs $5-7$

Mycobank MB811602,

Facesoffungi Number: FoF 01643

GenBank ENA, accession number LK39260

Etymology - Referring to the brown (5B5-8 to 5C6-8) coloration of the basidiome.

Pileus (Fig. 5A-D) 60-100 mm diam., very thin-fleshed, plano-convex and depressed when young, then infundibuliform when older; pellis wet, indehiscent, strongly striate near margin, smooth in the center; brownish orange to brownish yellow, darker in the center (5B5-8 to 5C6-8). Margin incurved to straight, finally uprolled. Lamellae adnate to subdecurrent, distinctly distant or spaced, rarely forked at the margin, very fragile and very brittle, unequal, regular pattern with 3 lamellulae between 2 lamellae, $(\mathrm{L}+\mathrm{l}=4-5 / \mathrm{cm})$, whitish to pale orange. Stipe concolorous to the pileus, $35-50 \times 10-13 \mathrm{~mm}$, cylindrical, central, tapering downwards, wet mat, fleshy and firm. Context of pileus very thin, slightly thick in the center, very fragile and brittle, stipe firm; whitish to pale orange (5A2-4). Latex abundant, whitish, changing slightly to green, taste and smell not special.

Basidiospores (Fig. 6E, 7A-B) broadly ellipsoid, 7.0- $\underline{8.5}-9.5 \times 6.0-6.5-7.0 \mu \mathrm{m}(\mathrm{Q}=1.17-1.2-$ 1.25-1.3-1.35; $\mathrm{n}=75$ ), ornamentation amyloid, composed of well-developed irregular, conical or rounded, and isolated warts; amyloid spot in the plage absent. Basidia (Fig. 6C) 50-75 $\times 9-10 \mu \mathrm{m}$; 4-spored; subcylindrical to subclavate, tapering downwards; sterigmata $3-5 \times 1.5-2.5 \mu \mathrm{m}$, well developed. Pleurocystidia (Fig. 6D) very abundant, 45-80 $\times 7-10 \mu \mathrm{m}$; irregularly shaped, subcylindrical, tortuous, much branched and commonly diverticulate, thin-walled, septate, apex tapering. Pleuropseudocystidia (Fig. 6B) not abundant, 6-10 $\mu \mathrm{m}$ diam.; emergent, irregularly 

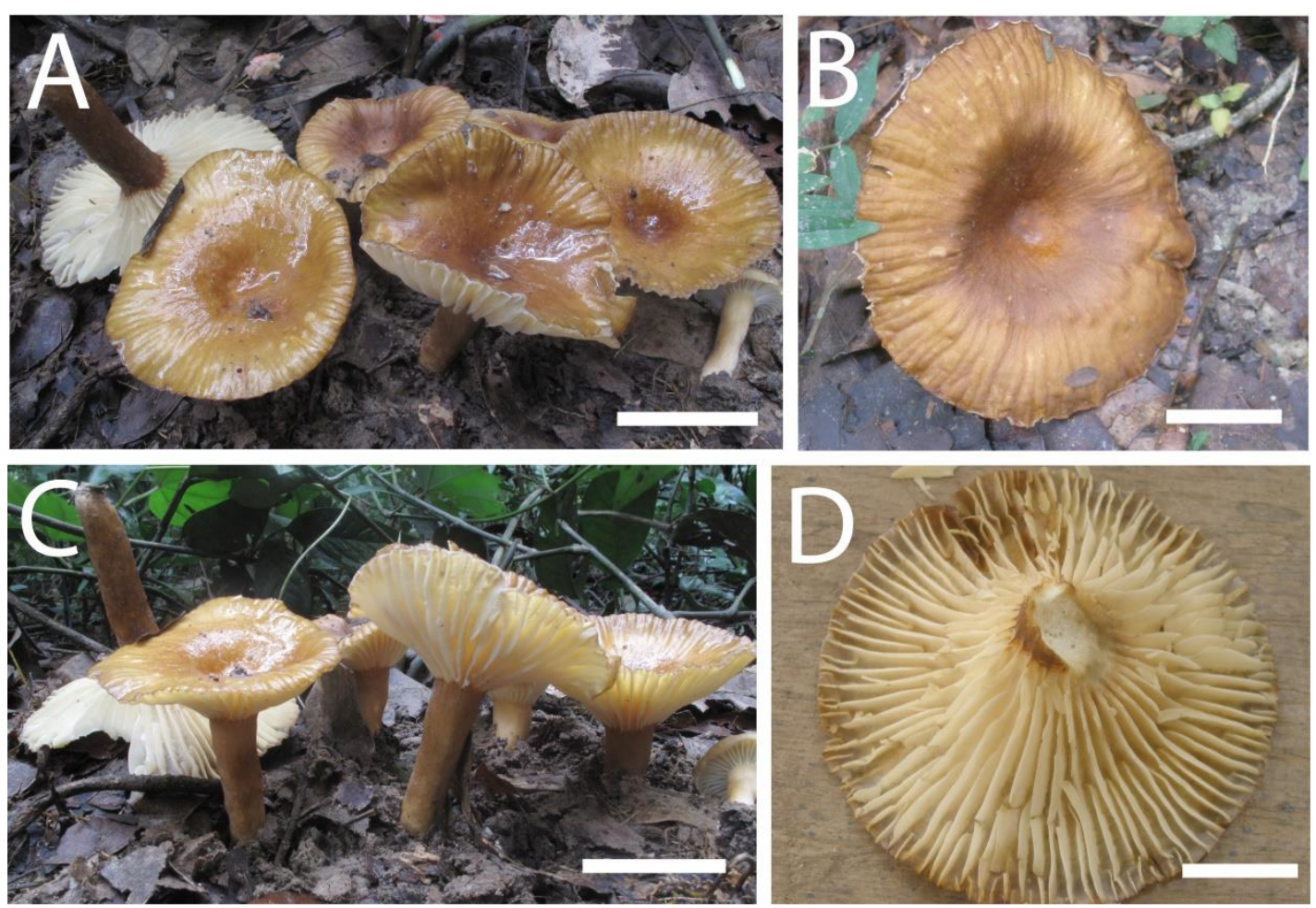

Fig. 5 - Basidiome of Lactifluus brunneocarpus. A, C. General detailed view (MD219B). B. Pileus view, pellis detailed (MD224). D. View of lamellae, detailed (MD224). - Scale Bars $=10 \mathrm{~mm}$.

subcylindrical, apex tapering sometimes inflated, content brown, needle-like. Hymenophoral trama mostly filamentous composed of a mixture of hyaline hyphae, sphaerocytes, and lactifers. Lamellae edge sterile. Marginal cells (Fig. 6F) 40-60 × 2-5 $\mu \mathrm{m}$, subcylindrical to cylindrical, sometimes septate sometimes frocked at apex. Pileipellis (Fig. 6A) a cutis to ixocutis-like, mono-layered, composed of interwoven horizontal, slightly ascending hyphae, thin-walled, septate, and often branched, in mixture with lactifers; terminal element 3-5 $\mu \mathrm{m}$ diam., cylindrical to subcylindrical. Stipitipellis identical to pileipellis. Clamps absent.

Material examined - Guinea, Malouwaita, N10³2'7.7" W09'22'8.6", on soil in rainforest dominated by Uapaca heudelotii, 18 July 2011 (collector) D.L. Maba, MD224 (TOGO, holotype), Isotype Munich (M); Guinea, Malouwaita, N08 19'7.3" W09 13'20.1", on soil in rainforest dominated by Uapaca heudelotii, 18 July 2011, (collector) D.L. Maba, MD219B (TOGO).

Known distribution - Guinea, Malouwaita.

Lactifluus burkinabei Maba, sp. nov.

Figs $8-10$

Mycobank MB811603

Facesoffungi Number: FoF 01644

Genbank ENA, accession number LK392609

Etymology - Referring to Burkina Faso, the country where the holotype was found.

Pileus (Fig. 8A-C) 60-105 mm diam., firm, fleshy and thick, plano-convex and depressed to infundibuliform, pellis wet, smooth, sticky; orange to deep orange (5A7-8). Margin smooth, inflected to downrolled. Lamellae broadly, decurrent, irregular, unequal $(\mathrm{L}+\mathrm{l}=8-9 / \mathrm{cm})$, very commonly forked, strongly anastomosing at the insertion of the stipe, widely spaced, light yellow to orange yellow (4A6-8). Stipe 15-40 × 10-15 mm, cylindrical, central and tapering downwards, dry matt, firm. Context fleshy and firm, pale yellow to butter yellow (3A5-4A5), thick in the center, and slightly thinner at the margin, stipe fleshy and firm. Latex slightly abundant, whitish, unchanging, taste bitter and spicy, smell not special.

Chemical reaction - changing to brown with $\mathrm{FeSO}_{4}$ on the context. 

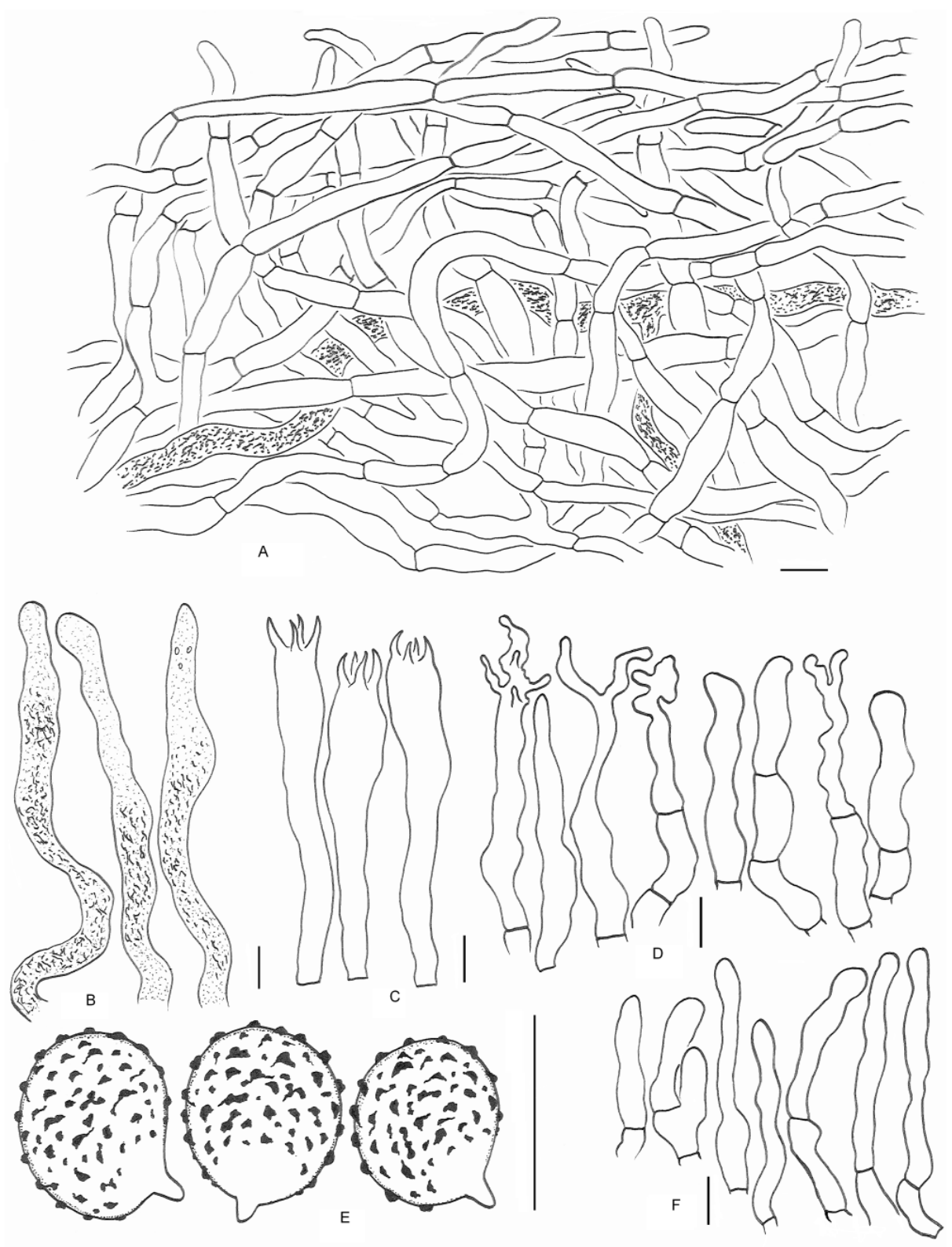

Fig. 6 - Light microscopy of Lactifluus brunneocarpus (MD224). A. Pileipellis. B. Pleuropseudocystidia. C. Basidia. D. Pleurocystidia. E. Basidiospores. F. Marginal cells. - Scale Bars $=10 \mu \mathrm{m}$. Section line drawing
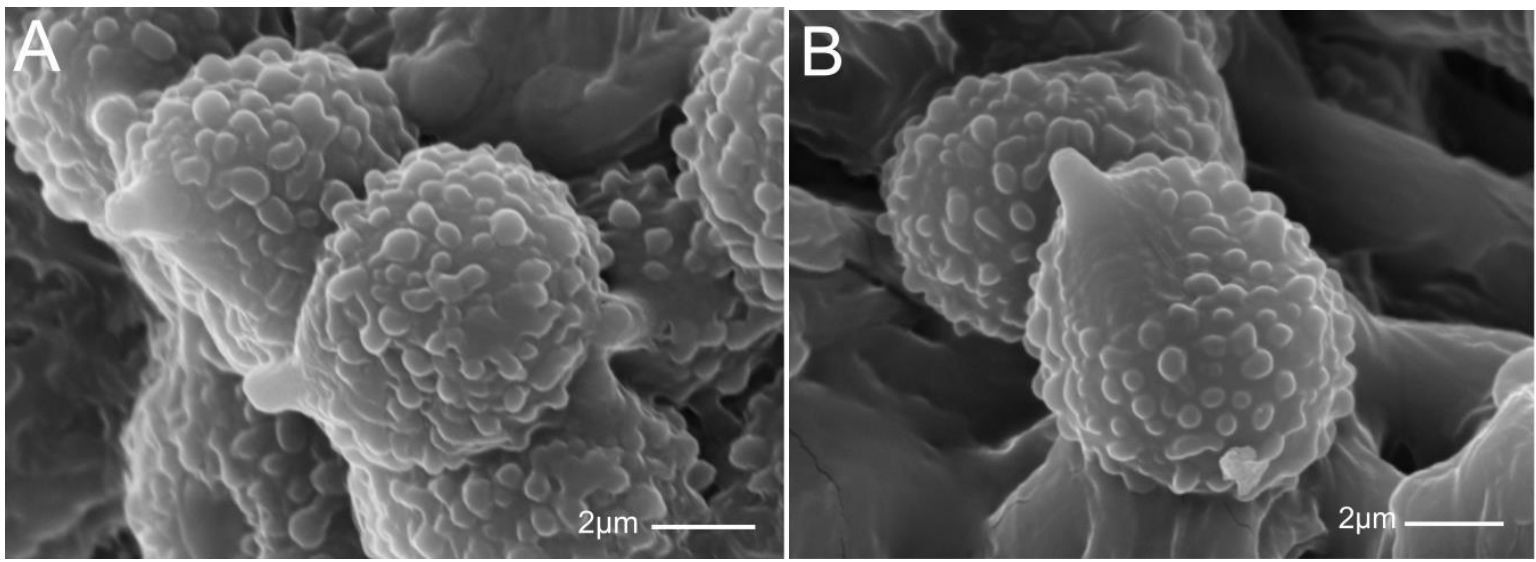

Fig. 7 - SEM of Lactifluus brunneocarpus (MD224). Basidiospores: A. Lateral front view. B. Proximal profile view showing the plage 

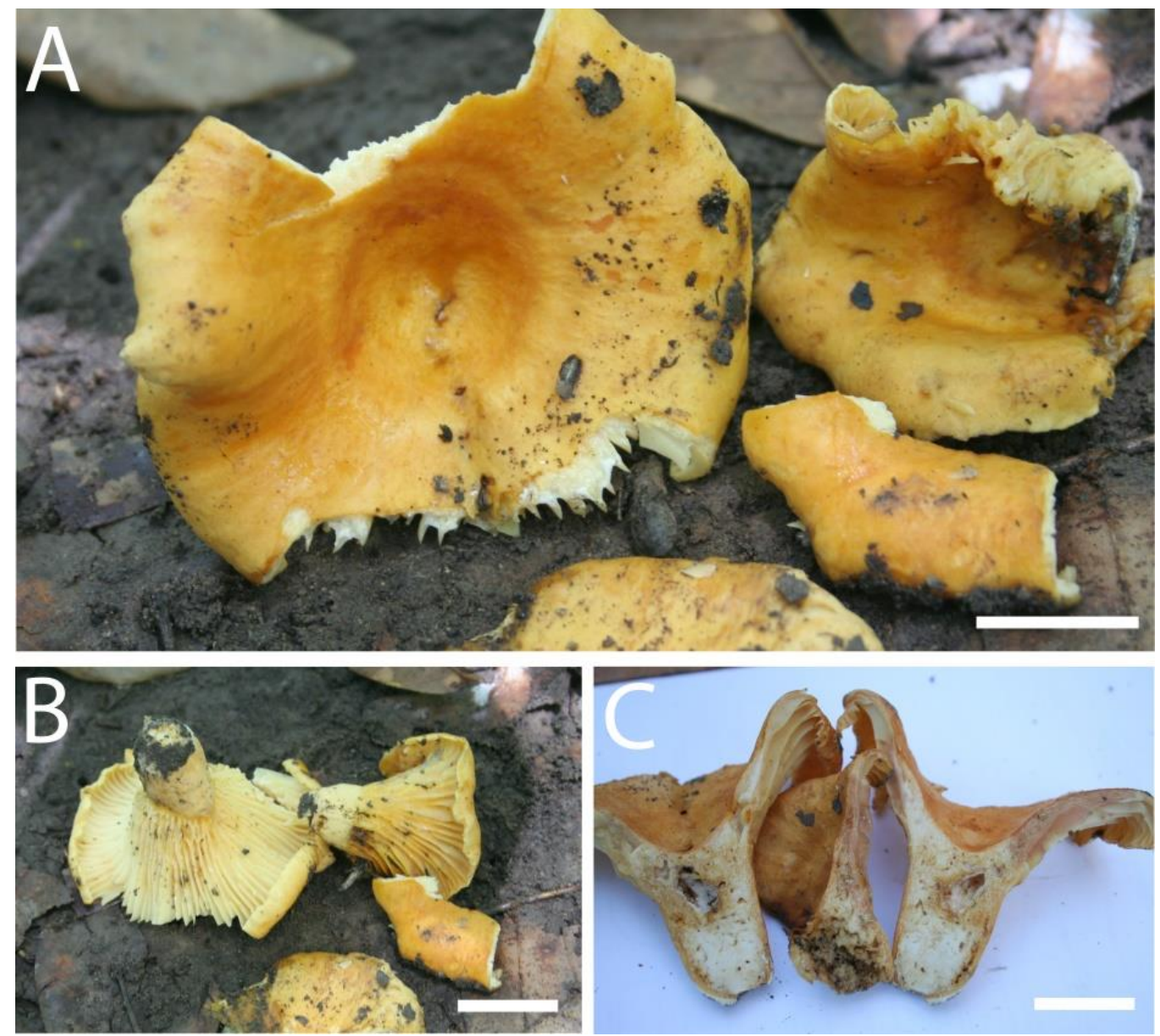

Fig. 8 - Basidiome of Lactifluus burkinabei (MD355). A. Pileus detailed. B. View of lamellae and stipe, detailed. C. View of context change with $\mathrm{FeSO}_{4}$ reagent. - Scale Bars $=10 \mathrm{~mm}$.

Basidiospores (Fig. 9G, Fig. 10B-C) subglobose to ellipsoid, 8.0-9.0-10 × 7.0-7.5-8.0 $\mu \mathrm{m}$ $(\mathrm{Q}=1.06-1.15-1.25 ; \mathrm{n}=75)$; ornamentation amyloid, composed of irregularly shaped warts, almost interconnected forming reticulum, and seldom isolated; plage with a strong amyloid spot. Basidia (Fig. 9C) $55-75 \times 10-12$ (13) $\mu \mathrm{m}$; variable, two- and four-spored; subcylindrical to subclavate; sterigmata 6-12 $\times 2-3 \mu \mathrm{m}$, sometimes with irregular shape, apex sometimes bulging or appearing swollen. Pleuroleptocystidia (Fig. 9E) very abundant, 60-75 $\times 10-13 \mu \mathrm{m}$; subcylindrical to subclavate, thin-walled, apex often tapering upwards, almost mucronate to rostrate, emergent. Pleuropseudocystidia (Fig. 9B) very abundant, 8-25 $\mu \mathrm{m}$ diam.; irregularly subcylindrical, mostly inflated, apex capitate to mucronate; very emergent and projecting up to $40 \mu \mathrm{m}$ above the hymenium; with irregular, needle-like, brown contents. Hymenophoral trama cellular composed of a mixture of sphaerocytes, and lactifers. Lamellae edge sterile. Marginal cells (Fig. 9D) 15-35 × 56(8) $\mu \mathrm{m}$, very variable in shape, cylindrical to subcylindrical, sometimes fusiform, sometimes septate; apex distinctly mucronate or flared. Pileipellis (Fig. 9A) an ixotrichopalisade to trichopalisade, with abundant clavate to subglobose cells (up to $50 \mu \mathrm{m}$ diam.), suprapellis elements subcylindrical sometimes fusiform, irregularly branched, septate. Dermatocystidia (Fig. 9F) abundant, 40-65 $\times$ 4-7 $\mu \mathrm{m}$, with mucronate to subcapitate apex, with needle-like contents. Stipitipellis a trichopalisade to lamprotrichopalisade, suprapellis composed of irregular elements, subcylindrical to subclavate, sometimes tortuous, septate; thick-walled elements present, in mixture with numerous interwoven lactifers. Clamps absent.

Material examined - Burkina Faso, Bobodiolasso, Orodara, DAN, N10 53'6.9" E04 ${ }^{\circ} 0^{\prime 27.9 ",}$ on soil in gallery forest dominated by Berlinia grandifolia and Uapaca guineensis, 12 July 2013, (collector) D.L. Maba, MD355 (TOGO, holotype), Isotype Munich (M).

Known distribution - Burkina Faso, Orodara. 

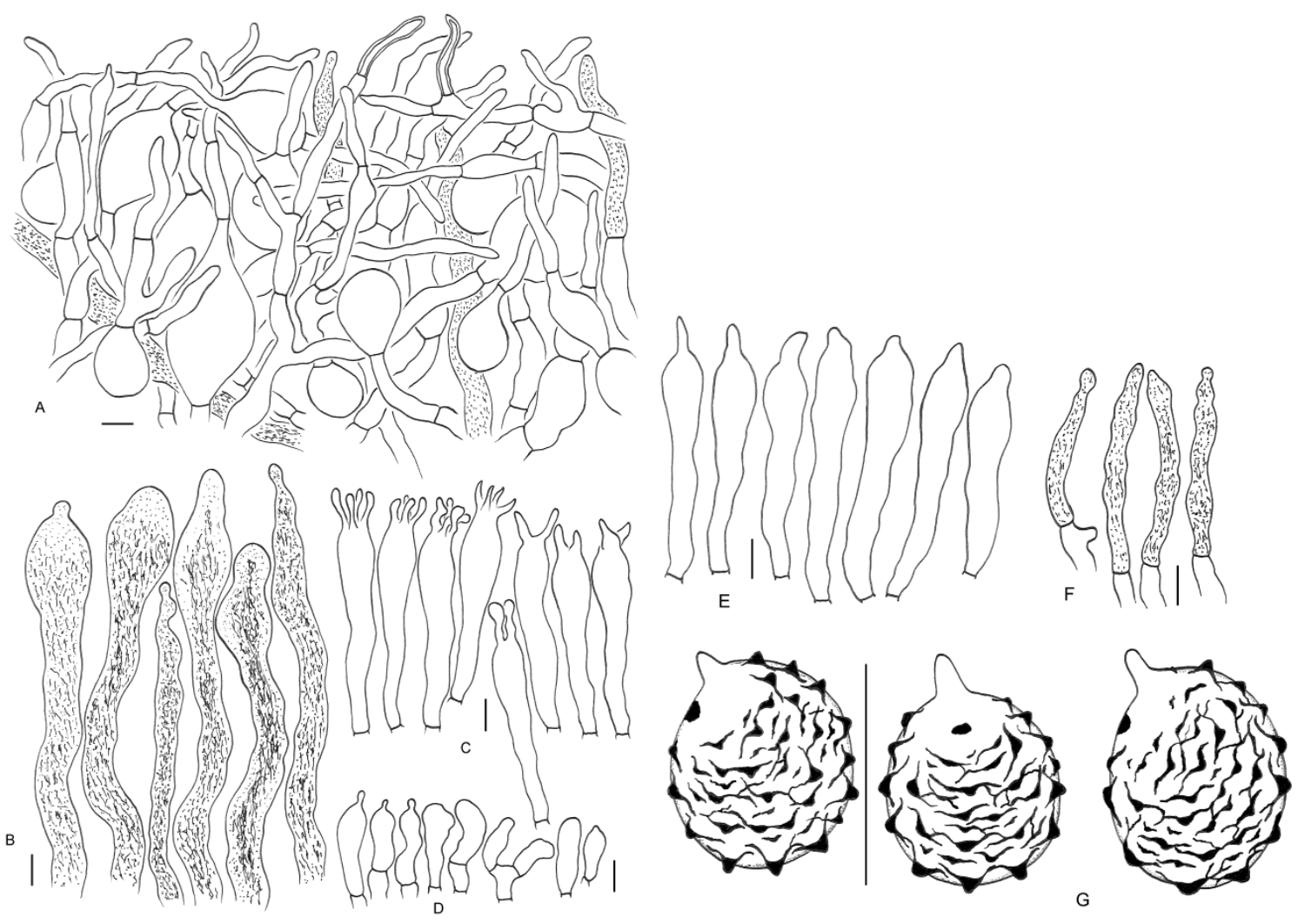

Fig. 9 - Light microscopy of Lactifluus burkinabei (MD355). A. Pileipellis. B. Pleuropseudocystidia. C. Basidia. D. Marginal cells. Hymenium. E. Pleurocystidia. F. Dermatocystidia. G. Basidiospores. - Scale Bars $=10 \mu \mathrm{m}$. Section line drawing.
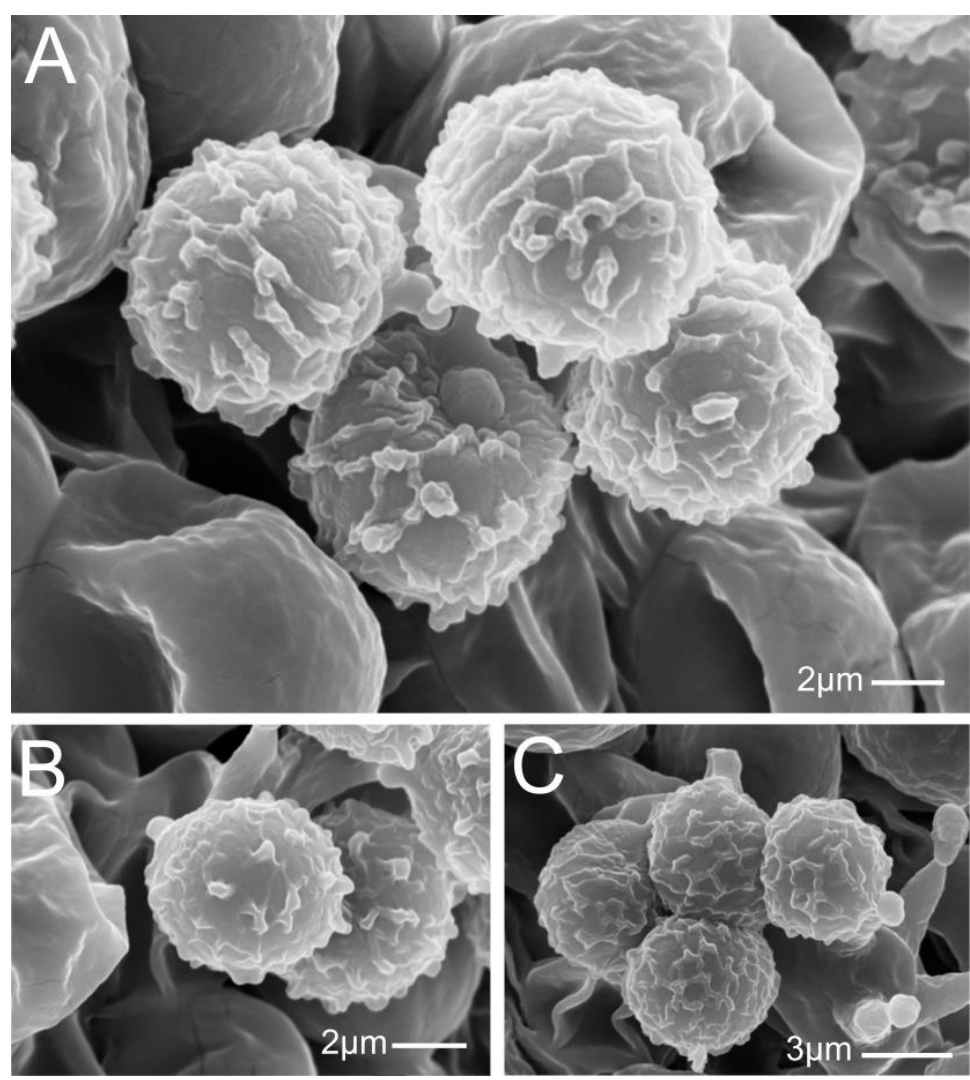

Fig. 10 - SEM of Lactifluus burkinabei (MD355). Basidiospores: A. Overview and detailed view showing the plage with amyloid spot. B. Lateral/dorsal view. C. Dorsal view. 
Etymology - In honour to Prof. Atsu Guelly, from the University of Lomé (Togo) for initiating and promoting studies on macromycetes in Togo.

Pileus (Fig. 11A-C) 35-60 $\mu \mathrm{m}$ diam., plano-convex, depressed to subinfundibuliform; pellis dehiscent, sticky, faintly striate when young and strongly striate near margin when older; orange white, pale orange to light orange (5A2-5) darker in center. Margin strongly striate, at first incurved then straight, crenulated to uprolled. Lamellae adnate to subdecurrent, spaced, unequal, irregular; 3 or 5 lamellulae between 2 lamellae $(\mathrm{L}+\mathrm{l}=5-7 / \mathrm{cm})$, sometimes bifurcate or forked at the margin (up to $1 / 3$ from margin), orange white. Stipe $25-30 \times 10-15 \mu \mathrm{m}$, cylindrical, tapering downwards, smooth, orange white. Context thin near margin, fleshy and firm in the center of the pileus and the stipe; whitish. Latex not abundant, whitish and unchanging.

Basidiospores (Fig. 12B, 13A-D) broadly ellipsoid to elongate, 7.5-9.5-10.5(11.5) $\times$ 6.5-7.58(8.5) $\mu \mathrm{m}(\mathrm{Q}=1.2-1.30-1.45 ; \mathrm{n}=65)$; ornamentation amyloid; composed of well-developed blunt warts $(>0.5 \mu \mathrm{m}$ high) connected by fine lines; plage with amyloid spot (Fig. 12, 13). Basidia (Fig. 12E) $45-70 \times 10-12 \mu \mathrm{m}$, subcylindrical, four-spored. Pleurocystidia (Fig. 12F) rather abundant, 45$75 \times 5-8 \mu \mathrm{m}$, irregularly shaped, subcylindrical, mostly tortuous to fusiform, thin-walled. Pleuropseudocystidia (Fig. 12D) very abundant, $4-15 \mu \mathrm{m}$ diam., tortuous to fusiform, tapering upwards, mucronate, emergent, contents needle-like and granular. Lamellar edge sterile. Hymenophoral trama cellular, mixture of sphaerocytes and laticifers. Marginal cells (Fig. 12C) 10$35 \times 4-8 \mu \mathrm{m}$, broadly clavate, subcylindrical to fusiform, thin-walled, bifurcate and septate. Pileipellis (Fig. 12A) lamprotrichoderm-like with abundant swollen hyphae; terminal hyphae sometimes thick-walled; pseudocystidia abundant, 5-8 $\mu \mathrm{m}$ diam., with needle-like contents. Stipitipellis mixed ixocutis-like, composed of subclavate, subcylindrical to fusiform hyphae, and interwoven hyphae with sometimes thick-walled apex. Clamps absent.

Material examined - Togo, Central region: Prefecture of Assoli, Reserve Forest of Aledjo N09 $16^{\prime} 53.7^{\prime \prime}$, E00113'41.2", gallery forest dominated by Berlinia grandiflora and Uapaca guineensis 26 May 2008, leg. A.K. Guelly, C2157 (TOGO, Holotype); Togo, Central region: Prefecture of Assoli, Reserve Forest of Aledjo N09¹6'53.7", E001'13'41.2", gallery forest dominated by Berlinia grandiflora and Uapaca guineensis 26 May 2008, leg. A.K. Guelly, C2163 (TOGO).

Known distribution - Togo, Aledjo Reserve Forest.

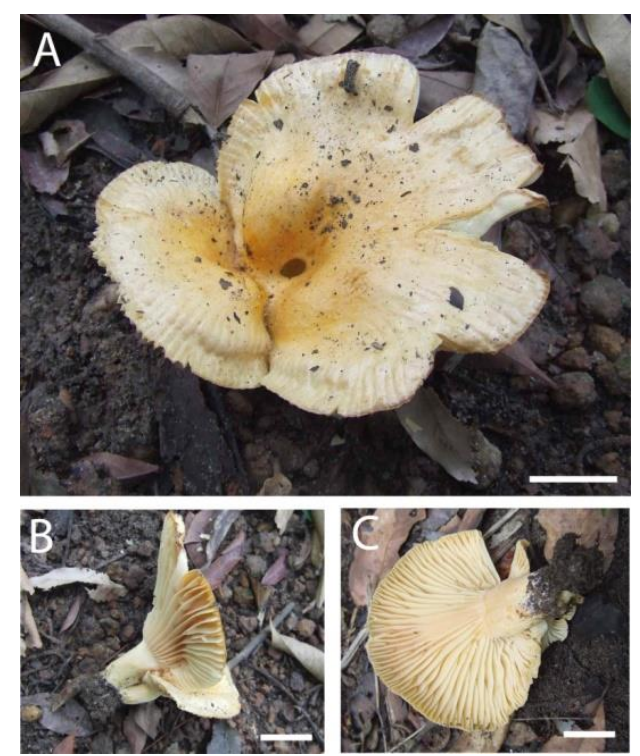

Fig. 11 - Basidiome of Lactifluus guellii (C2157). A. Pileus detailed. B. Lateral view of the lamellae and stipe. C. Detailed view lamellae and stipe. - Scale Bars $=10 \mathrm{~mm}$. 

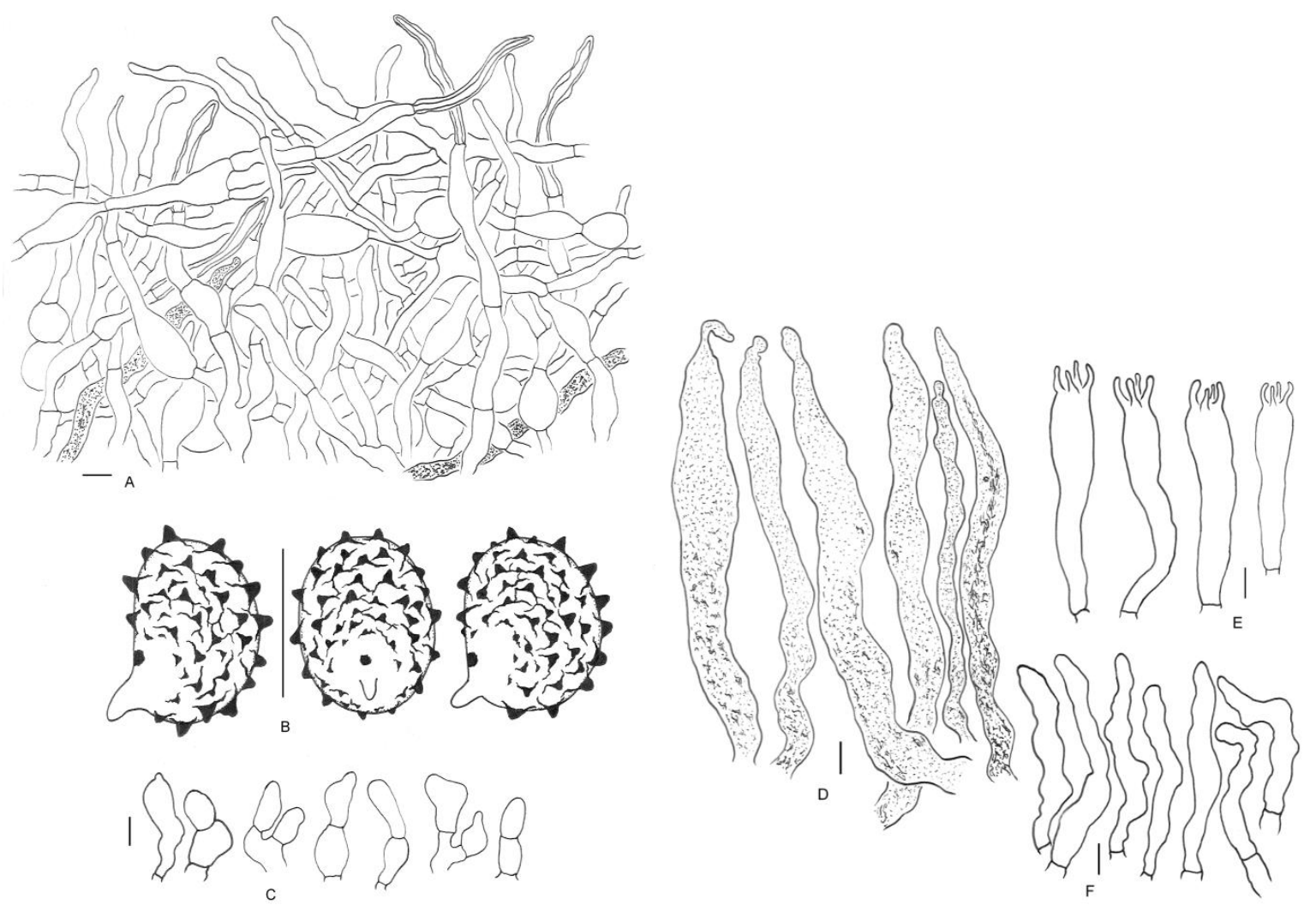

Fig. 12 - Light microscopy of Lactifluus guellii (C2157). A. Pileipellis B. Basidiospores. C. Marginal cells. D. Pleuropseudocystidia. E. Basidia. F. Pleurocystidia. - Scale Bars = $10 \mathrm{~mm}$. Section line drawing.
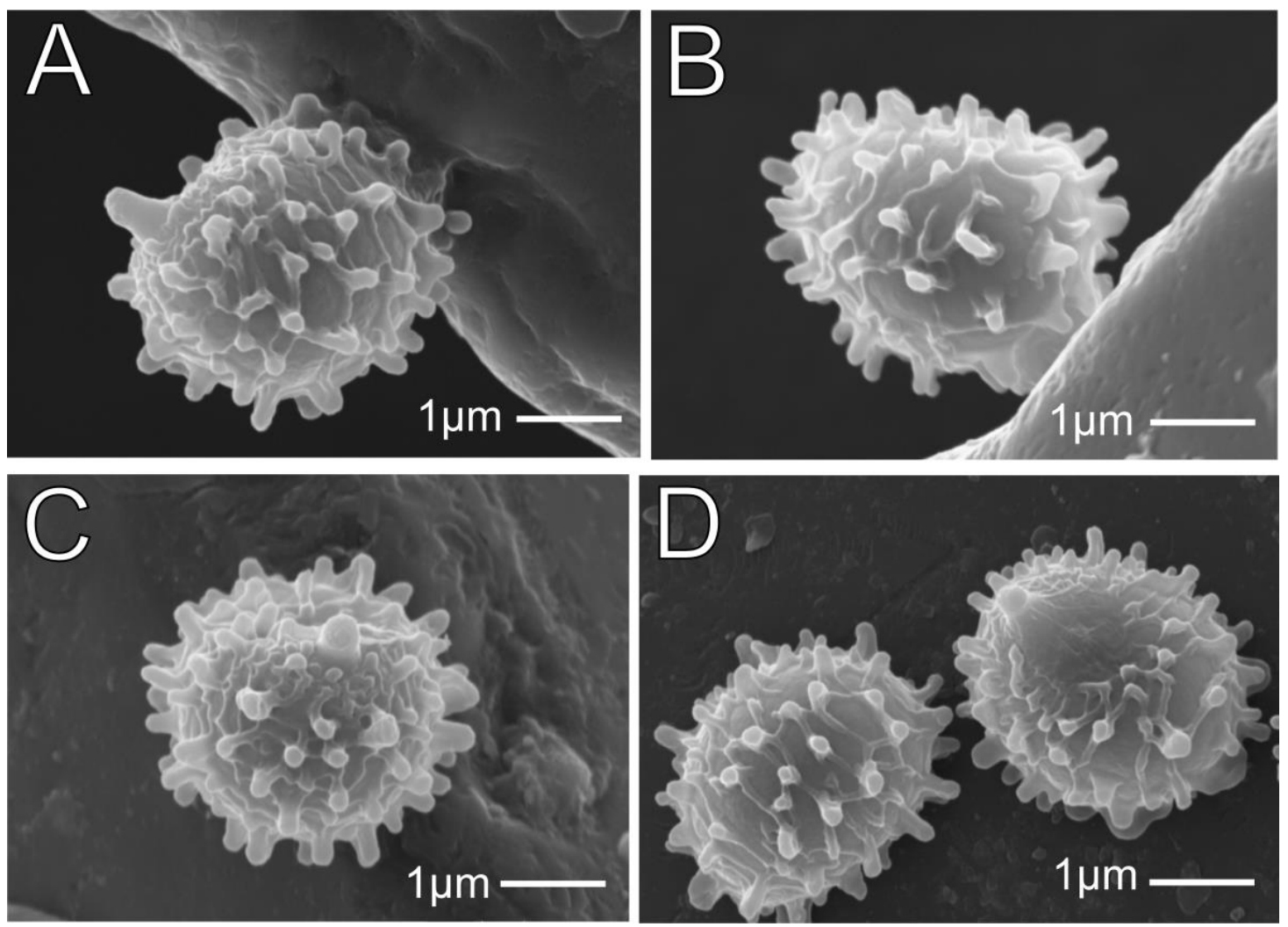

Fig. 13 - SEM of Lactifluus guellii (C2157). Basidiospores: A. Proximal view (left), lateral view (right). B. Dorsal view. C. Proximal view. 
Lactifluus membranaceus Maba, sp. nov.

Figs $14-16$

Mycobank MB811605

Facesoffungi Number: FoF 01646

Genbank ENA, accession number HG426478

Etymology - Referring to the remaining membranous-like velum that covers the pileus.

Pileus (Fig. 14A-C) 50-65 mm diam., convex when young, then plano-convex and depressed in the center, covered by a universal veil which initially enclosed the young basidiome; dry, velvety, uniform, membranous, smooth; beige (4BC3), orange white to yellow orange (4B5-8 to 5B4-6); remnants of secondary velum forming thin, and an evanescent annulus. Margin enrolled to incurved with remnants of secondary velum at margin. Lamellae thin, broadly decurrent, irregular, unequal $(\mathrm{L}+\mathrm{l}=6-7-8 / \mathrm{cm})$, very commonly forked, slightly dense, yellowish white to pale orange (4A4-5 to $5 \mathrm{~A} 3$ ). Stipe $40-55 \times 14 \mathrm{~mm}$, cylindrical, central, tapering downwards, velvety, dry matt, full and firm. Context of pileus pale orange, to orange white, thick in the center, slightly thinner at the margin, solid in the stipe. Latex not abundant or scarce, whitish, unchanging; taste and smell not special.

Basidiospores (Fig. 15E, 16A-D) globose to subglobose, sometimes ellipsoid, 7.0-7.58.0(8.5) $\times$ (5.5)6.0-7.0-7.5 $\mu \mathrm{m}, \quad(\mathrm{Q}=(1.04) 1.06-1.12-1.15(1.18) ; \mathrm{n}=75) . \quad$ Weak amyloid ornamentation composed of very short, fine lines-like, not well distinctive under light microscope; very low developed warts slightly connected under SEM; plage distinct with amyloid spot. Basidia (Fig. 15D) 35-57 $\times 8-10 \mu \mathrm{m}$, four-spored, subcylindrical to subclavate; sterigmata 7-8 $\times 1.5-2 \mu \mathrm{m}$. Pleurocystidia absent. Pleuropseudocystidia (Fig. 15C) very abundant, 6-15 (20) $\mu \mathrm{m}$ diam.; irregularly subcylindrical, slightly inflated, tapering upwards, very rarely tortuous, apex mucronate; projecting up to $40 \mu \mathrm{m}$ above the hymenium; with irregular dense brown, slightly needle-like contents. Hymenophoral trama heteromerous, composed of a mixture of filamentous hyphae, sphaerocytes, and laticifers. Lamellae edge sterile. Marginal cells (Fig. 15A) 20-35 × 5-6 $\mu$ m, distinctly cylindrical to subcylindrical, slightly fusiform, septate. Pileipellis (Fig. 15B) a lamprotrichopalisade, hyphae very thick-walled $(2-3 \mu \mathrm{m})$, suprapellis elements 60-150 × 3-5 $\mu \mathrm{m}$; slender, irregularly branched to diverticulate, very tortuous to fusiform, tapering upwards. Stipitipellis a lamprotrichopalisade, identical to pileipellis. Clamps absent.

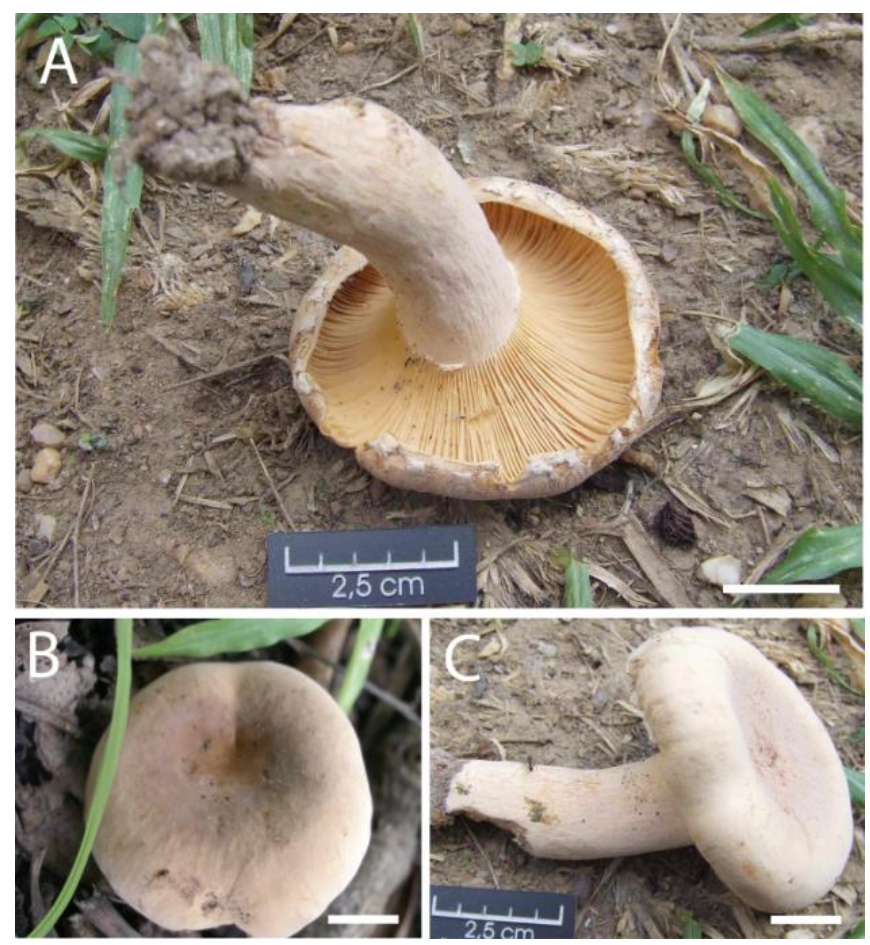

Fig. 14 - Basidiome of membranaceus. A. View of the lamellae and stipe (C2349). B-C. Pileus and stipe view, pellis detailed (B: MD234; C: C2349). - Scale Bars $=10 \mathrm{~mm}$. 

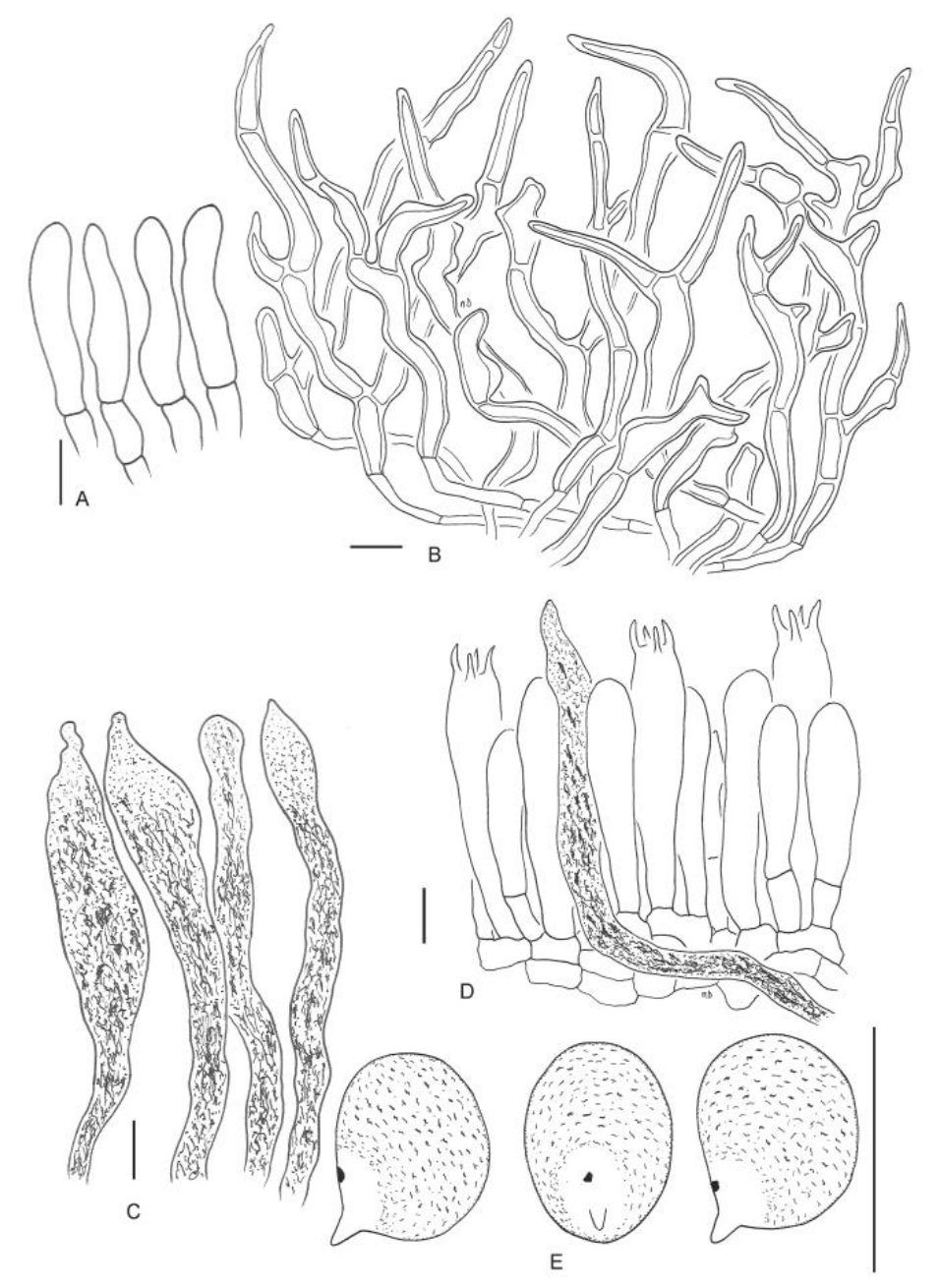

Fig. 15 - Light microscopy of Lactifluus membranaceus (C2349). A. Marginal cells. B. Pileipellis. C. Pleuropseudocystidia. D. Hymenium. E. Basidiospores. - Scale Bars $=10 \mu \mathrm{m}$. Section line drawing.
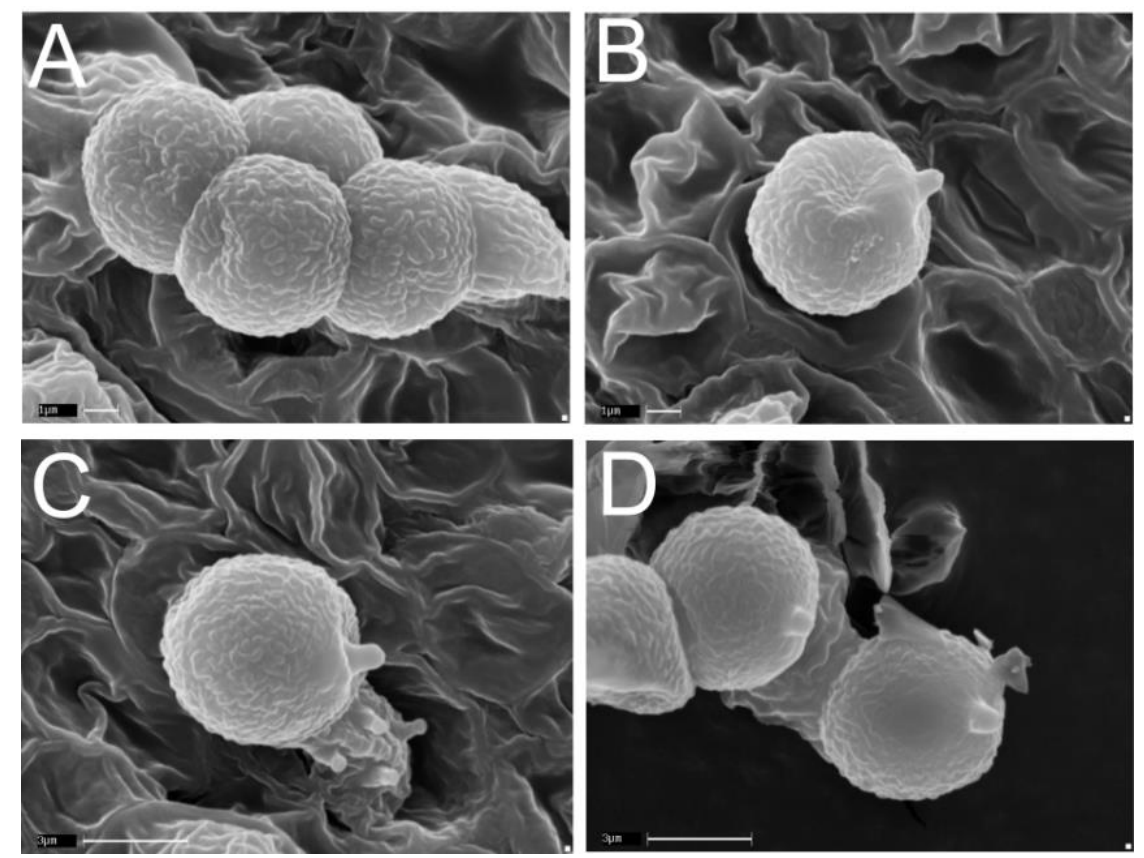

Fig. 16 - SEM of Lactifluus membranaceus (C2349). Basidiospores: A. Overview B-C-D Front. 
Material examined - Togo, Central region, Prefecture of Tchaoudjo, Fazao-Malfakassa National Park, N08 42'58" E00 $46^{\circ} 22^{\prime \prime}$, on soil in woodland dominated by Isoberlinia doka and Uapaca togoensis, 8 June 2008, (collector) D.L. Maba, C2349; (TOGO, holotype); Guinea, Malouwaita, N10 $32^{\prime} 5.7^{\prime \prime} \mathrm{W}^{\circ} 22^{\prime} 8.6^{\prime \prime}$, on soil in rainforest dominated by Uapaca heudelotii, 18 July 2011, (collector) D.L. Maba, MD234 (TOGO), ENA accession no. LK392610; Togo, Central region, Prefecture of Assoli, Reserve Forest of Aledjo N09'13.9'8.1" E01 11.4'42", on soil in woodland dominated by Isoberlinia tomentosa and Uapaca togoensis 12 July 2008, (collector) D.L. Maba, DPM05 (TOGO).

Known distribution - Togo, Fazao-Malfakassa National Park and Aledjo Reserve Forest; Guinea, Malouwaita

\section{Discussion}

\section{Lactifluus subgenus Lactariopsis}

Species Lactifluus annulatolongisporus and Lf. membranaceus described here fit the traditionally delimited $L f$. subg. Lactariopsis (Fig. 1) that encompasses all tropical African annulate lactarioid taxa, but also several without annulus. Both species present the following morphoanatomical characters that support their phylogenetic placement within Lf. subg. Lactariopsis: remnants of the secondary/partial velum forming an annulus, basidiome coloration (yellowish brown, yellowish orange, ochraceous, brownish orange, pale orange), pileus with dry and indehiscent pellis, latex scare and unchanging, lack of pleurocystidia, and presence of a lamprotrichopalisade as pileipellis and stipitipellis (Verbeken \& Walleyn 2010). Lactifluus annulatolongisporus is in some respect close to Lactifluus zenkeri due to its marginal cells that are branched, dichotomously bifurcate and tortuous (Fig. 3E); and to Lf. heimii (Verbeken) Verbeken, which has ellipsoid to elongate basidiospores up to $11.6 \mu \mathrm{m}$ long, and 1.64 for ratio (Verbeken \& Walleyn 2010). Lf. annulatolongisporus differs considerably from all hitherto examined members of Lf. subg. Lactariopsis possessing an annulus (Verbeken \& Walleyn 2010), by the presence of amyloid spot in the plage of its basidiospores; unlike $L f$. heimii and $L f$. zenkeri. The specimens examined (MD123 and MD131), present strongly bulbous to clavate pleuropseudocystidia, distinctly bulged in the middle, tapering up- and downward, sometimes branched or bifurcate, and are therefore different from those of $L f$. zenkeri and $L f$. heimii. Although morphologically different to $L f$. zenkeri, also by the basidiospores (size, ornementation and presence of amyloid spot), Lactifluus annulatolongisporus and Lf. zenkeri have branched, dichotomously bifurcate and tortuous marginal cells, unlike $L f$. heimii, which has the same elements that are shortly cylindrical to clavate (Verbeken \& Walleyn 2010). In addition, species including Lactifluus annulatoangustifolius (Verbeken) Verbeken, $L f$. heimii, Lf. velutissimus (Verbeken) Verbeken, $L f$. zenkeri and the newly described $L f$. annulatolongisporus, have lamprotrichopalisade to lampropalissade as peleipellis structure, which differs only by the sizes of terminal elements (Verbeken \& Walleyn 2010). Thus, the combination of morpho-anatomical characters of $L f$. annulatolongisporus distinguishes it from the other annulate species.

Lactifluus zenkeri is the one, in some respect, morpho-anatomically closest to the newly described Lactifluus membranaceus (specimens C2349, MD234 and DPM05). Both species have a velvety, indehiscent and dry pellis; remnants of secondary velum are membranous-like, forming a fragile and thin annulus. However, the pellis of Lactifluus membranaceus is beige, orange white to yellow orange colored, while it is whitish, yellowish brown to pale ochraceous, darker in the center for Lactifluus zenkeri (Verbeken \& Walleyn 2010). The microscopic examinations conducted have confirmed the dissimilarity between both species. Lactifluus zenkeri has utriform or tortuous to conical, dichotomously branched marginal cells, close to Lf. annulatolongisporus, scarce pleuropseudocystidia, basidiospores mostly ellipsoid, amyloid spot mostly absent in plage (Verbeken \& Walleyn 2010). On the contrary, Lf. membranaceus has distinctly cylindrical to 
subcylindrical, septate marginal cells (Fig. 15A), rarely fusiform, very abundant pleuropseudocystidia (Fig. 15C), and basidiospores (Fig. 15E, 16A-D) mostly globose to subglobose, with distinctly amyloid spot present in plage. Both $L f$. annulatolongisporus and $L f$. membranaceus fit $L f$. subg. Lactariopsis and their sequences are well supported in this subclade.

\section{Lactifluus subgenus Russulopsis}

Lactifluus brunneocarpus (specimens MD219B and MD224) has a brown colored pellis of the pileus, darker in the center and a stipe of similar colour, Latex changing slightly to green, basidiospore ornamentation composed of irregular, rounded, and obtuse warts isolated, and fits therefore Lf. subg. Russulopsis that encompasses some known species including Lf. ruvubuensis (Verbeken) Verbeken and Lf. longipes (Verbeken) Verbeken (Verbeken \& Walleyn 2010), with closely related characters. Morphologically $L f$. brunneocarpus presents wet, indehiscent, very fragile and brittle pellis, a strongly striate pileus of up to $2 / 3$ from the margin, very fragile, adnate to subdecurrent lamellae, with regular pattern of 3 , distinctly spaced lamellulae in between. In contrast, $L f$. longipes is morphologically identifiable by smooth, slightly concentrically zonate, radially wrinkled pileus, a long and slender stipe and very dense and frequently forked lamellae (Verbeken \& Walleyn 2010), while Lf. ruvubuensis has a thick basidiome with dehiscent, tomentose and finely fibrose towards the margin pellis, and unequal, strongly decurrent lamellae, according to Verbeken \& Walleyn (2010). Moreover, unlike Lf. longipes, which has long stipe (up to $80 \mathrm{~mm}$ high), $L f$. brunneocarpus has a stipe with measurements comprised between 35 and 50 $\mathrm{mm}$ high (for 11 different stipes sized). Microscopically, Lf. brunneocarpus differs from the two above mentioned closest species by its strongly diverticulate, branched and tortuous pleurocystidia (Fig. 6D) that are absent in Lf. longipes. But, in addition, pleuropseudocystidia are much branched and tortuous in both, Lf. ruvubuensis and Lf. longipes (Verbeken \& Walleyn 2010), while they are subcylindrical and slightly tapering upwards in Lf. brunneocarpus (Fig. 6B). The marginal cells of Lf. brunneocarpus (Fig. 6F) are subcylindrical and septate, and the basidiospores (Fig. 6E) present well-developed irregular, rounded to conical, and isolated amyloid warts as ornamentation unlike Lf. ruvubuensis. Lf. brunneocarpus even morpho-microscopically different from $L f$. ruvubuensis and $L f$. longipes as mentioned above, fits $L f$. subg. Russulopsis and its sequence forms a subclade with two sequences of $L f$. longipes, supported by $99 \%$.

\section{Lactifluus subgenus Edules}

The sequences of the newly described species $L f$. burkinabei (specimen MD355), and $L f$. guellii (specimen C2157), cluster within Lf. subg. Edules. Morphologically, Lf. burkinabei has firm, fleshy and thick pileus, wet and smooth pellis, very decurrent, commonly forked, and lamellae strongly anastomosing at the insertion of the stipe; its margin is smooth, inflected to downrolled. It differs thereby considerably to known Lactifluus species from tropical Africa (van Rooij and al. 2003; Verbeken \& Walleyn 2010). Microscopically, Lf. burkinabei has subglobose to ellipsoid basidiospores (Fig. 9G, 10A-C), with irregularly shaped amyloid warts, interconnected and forming a reticulum, seldomly isolated. It has additionally, two types of basidia (Fig. 9C): twospored (about $1 / 4$ to $1 / 3$ of the basidia) as those observed for Lf. inversus (Verbeken \& Walleyn 2010) and four-spored ones that both are subcylindrical to subclavate. Its pleuroleptocystidia (Fig. 8E) present almost mucronate to rostrate, often upwards tapering apices, closely related to those observed for $L f$. indusiatus Verbeken (Verbeken \& Walleyn 2010) of $L f$. sect. Chamaeleontini Verbeken. Lf. burkinabei presents an ixotrichopalisade to trichopalisade (Fig. 9A) pileipellis, composed of very abundant clavate to subglobose cells, in mixture with mucronate to subcapitate dermatocystidia (Fig. 9F); this pileipellis feature has never been observed for any known African lactarioids (van Rooij et al. 2003; Verbeken \& Walleyn 2010). Conversely, Lf. guellii (specimens C2157 and C2163) has indehiscent and very sticky; strongly striate pellis when old, and smooth in the center when young; strongly striate, incurved then straight, crenulated to uprolled margin; 
adnate to subdecurrent and spaced lamellae that are sometimes forked at the margin. Microscopically it has ellipsoid to elongate basidiospores (Fig. 12B, 13A-D), with strong, welldeveloped blunt amyloid warty ornamentation $(>0.5 \mu \mathrm{m}$ high), finely interconnected at the base, closely related to those observed in $L f$. melleus Maba (Maba et al. 2015). The pleurocystidia of $L f$. guellii (Fig. 12F) are irregularly shaped, mostly tortuous to fusiform in contrast to the pleuroleptocystidia of $L f$. burkinabei (Fig. 9E) that are almost mucronate to rostate with often upwards tapering apices. These features are unlike that of $L f$. melleus. Pleuropseudocystidia of $L f$. guellii (Fig. 12D) are emergent, fusiform, tortuous and mucronate, closely related to those of $L f$. corbula R. Heim \& Gooss.-Font. This latter mentioned species has a cutis-like pileipellis, cylindrical to subclavate marginal cells, and ellipsoid basidiospores (up to $10.4 \mu \mathrm{m}$ high, and up to 1.35 as ratio; $\mathrm{n}=60$ ) with no amyloid spot in plage (Verbeken \& Walleyn 2010). Lf. guellii on the contrary has lamprotrichoderm-like pileipellis, with abundant swollen hyphae; its marginal cells are broadly clavate, subcylindrical to fusiform, bifurcate and septate, and its basidiospores are broadly ellipsoid to elongate (up to $11.5 \mu \mathrm{m}$ high, and up to 1.45 as ratio; $n=65$ ), with strong amyloid spot in plage. In the phylogeny analyses, Lf. guellii is supported (97\%) as same species with one unidentified from Cameroon (UDB014027), with that it forms a terminal clade; together with $L f$. melleus a clade with $71 \%$ of bootstrap support. At the same time the sequence of $L f$. burkinabei is well supported by $99 \%$ as a subclade within subgenus Edules, the subgenus itself is supported by $86 \%$ of bootstrap support value.

\section{Ecology and occurrence of Lactifluus species in the Guineo-Sudanian domain}

Table 2 Occurrence of Lactifluus species in Sudanian woodlands, riverside and/or rain forests. +...: frequency of collections studied (based on collections from 2007 to 2013)

\begin{tabular}{|c|c|c|}
\hline \multirow[t]{2}{*}{ Species } & \multicolumn{2}{|l|}{ Occurrence } \\
\hline & Woodlands & Gallery forest \\
\hline Lactifluus annulatoangustifolius & ++++ & ++ \\
\hline Lf. annulatolongisporus & ++ & \\
\hline Lf. brunneocarpus & & ++ \\
\hline Lf. burkinabei & & + \\
\hline Lf. chamaeleontinus & & ++ \\
\hline Lf. densifolius & & ++++ \\
\hline Lf. edulis & + & + \\
\hline Lf. emergens & & ++ \\
\hline Lf. flavellus & & ++ \\
\hline Lf. fazaoensis & + & \\
\hline Lf. flammans & +++++ & ++ \\
\hline Lf. foetens & +++ & ++ \\
\hline Lf. guellis & & ++ \\
\hline Lf. gymnocarpus & ++ & ++ \\
\hline Lf. gymnocarpoides & ++++++++ & \\
\hline Lf. heimii & & + \\
\hline Lf. inversus & & + \\
\hline Lf. longibasidius & ++ & \\
\hline Lf. longipes & & ++++ \\
\hline Lf. luteopus & +++++ & ++++ \\
\hline Lf. medusae & ++ & \\
\hline Lf. melleus & ++ & \\
\hline Lf. membranaceus & ++++ & \\
\hline Lf. nonpiscis & + & +++ \\
\hline Lf. pectinatus & & + \\
\hline Lf. rubiginosus & & ++++ \\
\hline Lf. sudanicus & +++ & ++++ \\
\hline
\end{tabular}




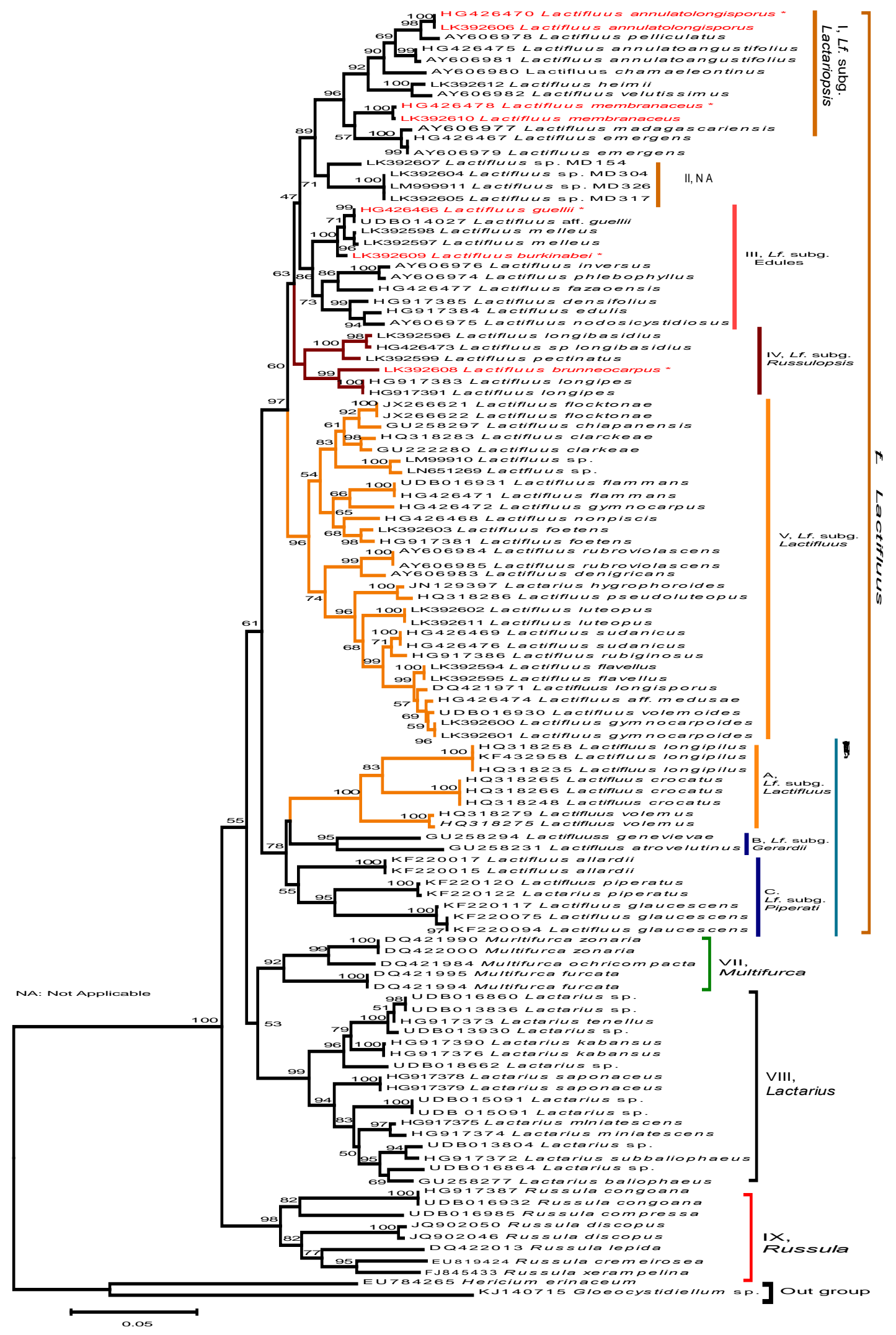

Fig. 17 - General phylogenetic tree obtained from 113 ITS sequences. Bootstrap values (in \%) are from maximum likelihood (ML) analyses (1000 bootstraps). Traditional taxa including genera and subgenera are demarcated. The Phylogenetic placement of our five newly described species: $L f$. annulatolongisporus, Lf. brunneocarpus, Lf. burkinabei, Lf. guellii and Lf. membranaceus is showing within the genus Lactifluus. (*) is mentioned in front of each holotype. 
Species of the genus Lactifluus are widespread in Guineo-Sudanian ecosystems and occur preferentially earliest between the end of May to July and latest between the end of August and September (Verbeken and Buyck 2001; van Rooij et al. 2003; Verbeken \& Walleyn 2010; Maba et al. 2013, 2014, 2015). In collections that have been continuously sampled since 2007 in various ectomycorrhizal dominated ecosystems, certain Lactifluus species including $L f$. annulatoangustifolius, Lf. edulis, Lf. foetens, Lf. gymnocarpus, Lf. luteopus, Lf. nonpiscis and Lf. sudanicus have shown no preference regarding vegetation type, as they had been collected in both woodlands and riverside/rain forests (Table 2). Lactifluus brunneocarpus, Lf. chamaeleontinus, Lf. densifolius, Lf. guellii, Lf. rubiginosus, Lf. longipes, and Lf. flavellus were collected only in riverside forests. Whereas $L f$. annulatolongisporus, $L f$. emergens, $L f$. gymnocarpoides, $L f$. medusae, $L f$. membranaceus, and $L f$. melleus were collected only in woodlands (supplement), Lf. flammans is collected mostly in woodlands (five times), but also in riverside forest (twice). Lactifluus burkinabei, Lf. fazaoensis, Lf. heimii, Lf. inversus, Lf. pectinatus were collected once, either in woodlands or in riverside forests. Thus, future additional mycological investigations including new inventories, should therefore contribute for better understanding of their ecological status including their distribution/occurrence, and phenology, and will also highlight whether any species are endemic in the Sudanian domain.

In contrast, some species including $L f$. medusae, Lf. densifolius, Lf. edules, Lf. heimii, $L f$. velutissimus are not restricted to Zambezian domain as suggested by Verbeken and Buyck (2001), as the recent mycological investigations have provided collections from Sudanian domain (Maba et al. 2013, 2015). Additionally, the occurrence in both Guineo-Sudanian and Congo-Zambezian domain, in woodland or in riverside forests, of numerous Lactifluus species including $L f$. annulatoangustifolius, Lf. aurantiifolius, Lf. chamaeleontinus, Lf. carmineus, Lf. densifolius, Lf. edulis, Lf. emergens, Lf. flammans, Lf. gymnocarpus, Lf. gymnocarpoides, Lf. heimii, Lf. inversus, Lf. luteopus, Lf. medusae Lf. nonpiscis, Lf. longipes, Lf. longisporus, Lf. pelliculatus, Lf. pumilus, Lf. rubiginosus, Lf. ruvubuensis, Lf. sesemotani, Lf. velutissimus, Lf. volemoides and $L f$. zenkeri (Table 2), confirm that in both the Guineo-Sudanian and the Congo-Zambezian domain, several common species occur as mentioned by Verbeken and Buyck (2001). Clearly, as suggested by the latter cited authors, many common Lactifluus and Lactarius species still need to be described from both domains.

Species of the genus Lactifluus are common and widespread in Guineo-Sudanian forest ecosystems, and display important anatomical features (Maba et al. 2013, 2015) of taxonomic relevance. The present study and the previously undertaken (Maba et al. 2013, 2015) support the high species richness of the genus Lactifluus in tropical Africa. This study provided additional new Lactifluus species of tropical African domains, and in some respect supports those of Van de Putte et al. (2009, 2010), and De Crop et al. (2014), which have suggested that the genus Lactifluus contains cryptic and/or semi-cryptic species, based respectively on investigations undertaken within $L f$. subg. Lactifluus, section- Lactifluus, and Lf. subg. Piperati, section Piperati. Evidently, a combination of anatomical and molecular analyses is the best way for interspecific discrimination, as well as species richness assessment by providing relevant arguments for supporting or denying traditional morphological diagnosis for species identification. In addition, West African forests ecosystems remain very poorly investigated. Thus, continuous specimen sampling/collecting as well as accelerated DNA sequencing and anatomical characterization of ectomycorrhizae, will contribute to a better understanding of ecological process within this genus.

\section{Acknowledgement}

We are much indebted to the International Foundation of Sciences (IFS, grant D/5178-1) for financial support and the German Academic Exchange Service (DAAD, grant A/11/72562). Special thanks to Eva Facher from the Department Biologie I, Ludwig-Maximilians-Universität, München, for the obtained SEM-pictures of spores, André De Kesel from National Botanic Garden, Belgium, and Annemieke Verbeken from Ghent University, Belgium, for their valuable instructions and advices during collecting trips and species identification. 


\section{References}

Buyck B. 1991 - The study of microscopic features in Russula. 1. Spores and Basidia. Russulales News 1, 8-26.

Buyck B, Hofstetter V, Eberhardt U, Verbeken A \& Kauff F. 2008 - Walking the thin line between Russula and Lactarius: the dilemma of Russula subsect. Ochricompactae. Fungal Diversity $28,15-40$.

De Crop E, Nuytinck J, Van de Putte K, Lecomte M, Eberhardt U, Verbeken A. 2014 - Lactifluus piperatus (Russulales, Basidiomycota) and allied species in Western Europe and a preliminary overview of the group worldwide. Mycological Progress 13, 493-511.

De Crop E, Tibuhwa D, Baribwegure D, Verbeken A 2012 - Lactifluus kigomaensis sp. nov. from Kigoma Province, Tanzani. Cryptogamie Mycolologie 33(4): 421-426.

Diédhiou AG, Ebenye HCM, Selossé MA, Awana NO, Bâ AM 2013 - Diversity and community structure of ectomycorrhizal fungi in mixed and monodominant African tropical rainforest. In Tropical and Neotropical forest. (eds) Bâ AM, McGuire KL and Diédhiou AG. 2013 - CRC Press.

Gardes M and Bruns TD. 1993 - ITS primers with enhanced specificity for basidiomycetes application to the identification of mycorrhizes and rusts. Molecular Ecology 2, 113-118.

Kornerup A \& Wanscher JH 1978 - Methuen Handbook of Colour. Methuen, London.

Maba DL, Guelly AK, Yorou NS, Verbeken A \& Agerer R. 2013 - Two New Lactifluus species (Basidiomycota, Russulales) from Fazao Malfakassa National Park (Togo, West Africa), Mycological Progress 13, 513-524.

Maba DL, Guelly AK, Yorou NS, De Kesel A, Verbeken A \& Agerer R. 2014 - The genus Lactarius s. str. (Basidiomycota, Russulales) in Togo (West Africa): phylogeny and a new species described. IMA Fungus 5, 39-49.

Maba DL, Guelly AK, Yorou NS, Verbeken A \& Agerer R. 2015 - Phylogeny and microscopic studies within the genus Lactifluus (Basidiomycota, Russulales) in West Africa including four new species. IMA fungus 6, 13-24.

Rivière T, Diédhiou AG, Diabaté M, Senthilarasu G, Hatarajan K, Verbeken A, Buyck B, Dreyfus B, Béna G, Bâ AM. 2007 - Genetic diversity of ectomycorrhizal Basidiomycetes from African and Indian tropical rain forests. Mycorrhiza 17, 415-428.

Sanon E, Guissou KM-L, Yorou NS \& Buyck B. 2014 - Le genre Russula au Burkina Faso (Afrique de l'Ouest): quelques espèces nouvelles de couleur brunâtre. Cryptogamie, Mycologie 35, 377-397.

Sanon KB, Bâ AM and Duponnois R. 2013 - Diversity and Function of Ectomycorrhiza between Scleroderma and Afzelia species in Burkina Faso. In Ectomycorriizal symbioses. In Tropical and Neotropical forest. (eds) Bâ AM, McGuire KL and Diédhiou AG. 2013 - CRC Press

Stubbe D, Nuytinck J, Verbeken A. 2010 - Critical assessment of the Lactarius gerardii species complex (Russulales). Fungal Biology 114, 271-283.

Thiers B. 2012 - Index Herbariorum: a global directory of public herbaria and associated staff. New York Garden's Virtual Herbarium. < http://sweetgum.nybg.org/ih/> access 19 January 2012

Van De Putte K, De Kesel A, Nuytinck J \& Verbeken A. 2009 - A new Lactarius species from Togo with an isolated phylogenetic position. Cryptogamie Mycologia 30, 39-44.

Van de Putte K, Nuytinck J, Stubbe D, Le HT \& Verbeken A. 2010 - Lactarius volemus sensu lato (Russulales) from northern Thailand: morphological and phylogenetic species concepts explored. Fungal Diversity 45, 99-130.

van Rooij P, De Kesel A \& Verbeken A. 2003 - Studies in tropical African Lactarius species (Russulales, Basidiomycota) 11. Records from Benin. Nova Hedwigia 77, 221-251.

Verbeken A, Buyck B. 2001 - Diversity and ecology of tropical ectomycorrhizal fungi in Africa. In: Tropical Mycology (Watling R, Frankland JC, Ainsworth AM, Isaac S, Robinson G, eds): 11-24. Wallingford: CABI Publishing. 
Verbeken A, Stubbe D, Nuytinck J. - 2008 Two new Lactarius species from Cameroon. Cryptogamie Mycologie. 29, 137-143.

Verbeken A \& Walleyn R. 2010 - Monograph of Lactarius in Tropical Africa. National Botanic Garden of Belgium Fungus Flora of Tropical Africa, Vol. 2. 161 p.54 pl

Verbeken A, Nuytinck J \& Buyck B. 2011 - New combinations in Lactifluus. 1. Lactifluus subgenera Edules, Lactariopsis, and Russulopsis. Mycotaxon 118, 447-453.

Verbeken A, Van De Putte K \& De Crop E. 2012 - New combinations in Lactifluus. 3. Lactifluus subgenera Lactifluus and subgenera Piperati. Mycotaxon 120, 443-450.

Verbeken A \& Nuytinck J. 2013 - Not every milkcap is a Lactarius. Scripta Botanica Belgica 51, $162-168$.

Yorou NS, Diabaté M, Agerer R. 2011 - Phylogenetic placement and anatomical characterization of two new West African Tomentella (Basidiomycota, Fungi) species. Mycological Progress 11, 171-180.

Yorou NS, Gardt S, Diabaté M, Guissou M-L, Agerer R. 2012 - Three new Tomentella species from West Africa identified by anatomical and molecular data. Mycological Progress 11, 449-462. 